\title{
Chemical characteristics of groundwater around two massive sulphide deposits in an area of previous mining contamination, Iberian Pyrite Belt, Spain
}

\author{
Hélène Pauwels $^{\mathrm{a}, *}$, Marie-Lou Tercier-Waeber ${ }^{\mathrm{b}}$, Miguel Arenas ${ }^{\mathrm{c}}$, \\ Ricardo Castroviejo ${ }^{\mathrm{d}}$, Yves Deschamps ${ }^{\mathrm{a}}$, Arnault Lassin ${ }^{\mathrm{a}}$, Flavio Graziottin ${ }^{\mathrm{e}}$, \\ Francisco-Javier Elorza ${ }^{\mathrm{d}}$ \\ ${ }^{a}$ Centre Scientifique et Technique, BRGM Research Division, B.P. 6009, 3 Avenue Claude Guillemin, 45060 Orleans Cedex 2, France \\ ${ }^{\mathrm{b}}$ CABE, Department of Inorganic, Analytical and Applied Chemistry, University of Geneva Sciences II, 30 quai Ansermet, \\ 1211 Geneva 4, Switzerland \\ ${ }^{\mathrm{c}}$ Inima S.A., Arturo Soria No. 336, 6a Plant ${ }^{a}, 28033$ Madrid, Spain \\ ${ }^{\mathrm{d}}$ ETSI Minas, U.P. Madrid, Rios Rosas No. 21, 28003 Madrid, Spain

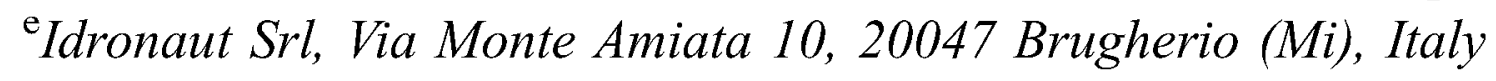

\begin{abstract}
A detailed chemical study of groundwater was carried out to elucidate the processes controlling the oxidation and dissolution of sulphide minerals at two massive sulphide deposits in the Iberian Pyrite Belt (IPB), i.e. the mined La Zarza deposit and the unmined Masa Valverde deposit. It was found that major-element compositions varied according to the hydrological regime, La Zarza being in a relatively high area with groundwater recharge (and disturbance due to the human factor) and Masa Valverde being in a relatively low area with groundwater discharge. The variations mainly concern $\mathrm{pH}, \mathrm{Eh}, \mathrm{SO}_{4}$ and $\mathrm{Na}$ concentrations. Metal concentrations were determined (a) by ICP-MS after filtration, and (b) in some cases by voltammetric measurement of $\mathrm{Cu}, \mathrm{Pb}, \mathrm{Zn}, \mathrm{Cd}$ and $\mathrm{Mn}$ using the Voltammetric In situ Profiling (VIP) System, which allows detection of only the mobile fractions of trace elements (i.e., free metal ions and small labile complexes a few nanometers in size). If one compares the results obtained by each of the two methods, it would appear that the groundwater shows significant enhancement of metal solubility through complexing with organic matter and/or adsorption onto colloids and/or small particles. In areas of sulphide oxidation, however, this solubility enhancement decreases according to $\mathrm{Cu}>\mathrm{Zn}>\mathrm{Cd}>\mathrm{Pb}$. Under very low redox conditions, the attained metal concentrations can be several orders of magnitude (up to $10^{8}-10^{9}$ for $\mathrm{Cu}$ and $10^{2}-10^{3}$ for $\mathrm{Pb}$ ) larger than those expected from equilibrium with respect to sulphide minerals as calculated with the EQ3NR geochemical code; $\mathrm{Zn}$ concentrations, however, are close to equilibrium with respect to sphalerite. The implication of these results is discussed with respect both to mineral exploration and to environmental issues.
\end{abstract}




\section{Introduction}

It is well established that natural baseline water purity can be affected by undisturbed mineralization; historic documents provide numerous examples of natural metal-rich surface waters due to the presence of unworked ore deposits (Runnells et al., 1992). The high metal concentrations and acidity observed in waters from such areas depend on several parameters and processes, such as the depth and permeability of the ore deposits, the type and abundance of the metalbearing sulphides, and the buffering capabilities of the host rock. Consequently, metal and $\mathrm{pH}$ anomalies have been proposed as tools for mineral exploration (de Geoffrey et al., 1967; Archer and Main, 1971; Shartsev et al., 1975; Cameron, 1977, 1978; Simpson et al., 1996; Taufen, 1997). From the environmental standpoint, however, high metal contents and low $\mathrm{pH}$ are toxic to flora and fauna and, under certain circumstances, this natural baseline water quality can even threaten aquatic ecosystems downstream from the ore deposit (Cameron et al., 1998).

For this reason, recent investigations on natural background concentrations in mineralized districts have been directed at setting water-quality limits for future remediation of acid-mine drainage (Duttweiller Kelley and Taylor, 1997; Leybourne et al., 1998), because it is both more cost-efficient and technologically easier to remediate a site to its natural level of contamination prior to mining rather than to attempt to impose higher quality standards.

Whether the objective has been mineral exploration or environmental assessment and improvement, studies have focused mainly on surface water or very shallow groundwater where chemical compositions are acquired primarily through oxidation of the deposits. Far less attention has been paid to deeper groundwater and the effects that orebodies at depths of tens, if not hundreds, of metres have on its composition. In the present paper, we record and compare the geochemistry of groundwater around and away from two massive sulphide deposits in the Iberian Pyrite Belt, Spain, which is an area of historic mining contamination. ${ }^{1}$

\footnotetext{
1 The potential damage that can result form mining contamination is exemplified by the disastrous accident of 25 April 1998 when spillage from the Los Frailes mine released 5 million $\mathrm{m}^{3}$ of toxic metal-rich acid waste and severely impacted the Donana National and Natural Parks.
}

The main purpose of the study was to determine the water-rock interactions at each site, i.e. La Zarza, which was mined until 1991, and Masa Valerde, which is undisturbed and deeply buried. Emphasis was placed on determining the effect of the deeply buried orebody on groundwater composition, despite the very low oxygen availability and lack of significant oxidation. This included an investigation of metals speciation and the solubility-controlling role of complexants. We also examine the potential role of groundwater chemical composition as an exploration tool, even in areas of previous mining contamination, and the relevance of baseline studies in helping to plan remediation and monitoring prior to mining.

\section{Study areas}

\subsection{General setting}

The La Zarza and Masa Valverde massive sulphide deposits are located in the Iberian Pyrite Belt (IPB), which is $250 \mathrm{~km}$ long by $25-70 \mathrm{~km}$ wide and forms part of the South Portuguese Zone of the Iberian Massif (Fig. 1). The IPB is made up of Late Devonian to Early Carboniferous rocks, in places overlain by TertiaryQuaternary units and alluvium (Van den Boogaard, 1967; Schermerhorn, 1971; Strauss and Madel, 1974; Routhier et al., 1980; Oliveira, 1990). The three main lithostratigraphic units are: (1) phyllites and quartzites (PQ, Late Devonian) comprising metamorphosed shale and quartz sandstone with rare conglomerate, and an upper sequence containing bioclastic carbonate lenses and nodules; (2) a thick ( $100-600 \mathrm{~m})$ Late Famenian to Middle Visean volcano-sedimentary sequence (VS) comprising bimodal shallow submarine volcanism with three rhyolitic sequences $(\mathrm{Rb} / \mathrm{Sr}=385 \pm 40 \mathrm{Ma}$; Hamet and Delcey, 1971) interlayered with basic volcanics and purple, blue and black shales, and (3) a thick turbiditic formation (Culm facies) that is diachronous over the underlying rocks (Late Visean to Westphalian). The Culm forms a southwestward prograding detrital cover beginning with shaly and ashlayer deposits $(0-200 \mathrm{~m})$ followed by turbidite facies (greywackes).

The structure of the IPB, acquired during the Variscan orogeny (initiated during the Late Visean and culminating during the major Middle Westphalian 


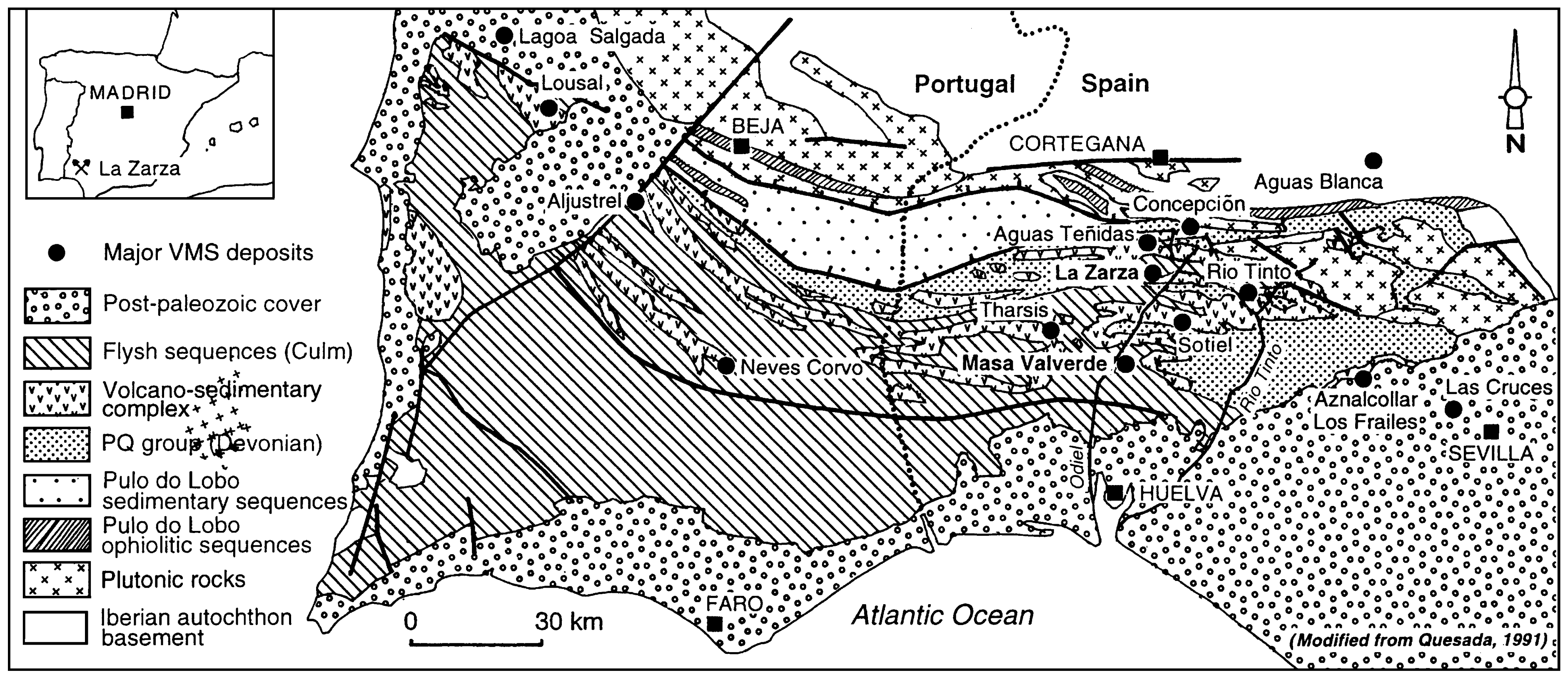

Fig. 1. Simplified geological map of the Iberian Pyrite Belt and location of the main deposits (modified from Quesada, 1991). 
phase), can be defined as "a thin-skinned foreland thrust and fold belt" (Silva et al., 1990; Quesada, 1991). The south-verging deformation is marked by three successive phases of compression under epizonal-metamorphic conditions that resulted in a north to south overthrusting accompanied by diachronous deposition of the Culm flysch sediments at the thrust front (Oliveira, 1990).

The volcanogenic massive sulphides (VMS) are hosted by the VS sequence, and either lie directly on acid volcanic facies units or are hosted by black shales, both situations being lateral to the acid volcanic centres. The 80 known deposits of the IPB contain more than $1700 \mathrm{Mt}$ of sulphide ore (mine$\mathrm{d}+$ reserves) totalling $14.6 \mathrm{Mt} \mathrm{Cu}, 13 \mathrm{Mt} \mathrm{Pb}, 34.9 \mathrm{Mt}$ $\mathrm{Zn}, 880 \mathrm{t} \mathrm{Au}$ and 46,100 t Ag (Leistel et al., 1998). Byproducts and trace metals (e.g., Sn, Cd, Co, Hg, Bi and $\mathrm{Se}$ ) are also reported in concentrations ranging from tens to hundreds of ppm. The VMS include several major deposits, such as Rio Tinto $(>234 \mathrm{Mt})$, Neves-Corvo ( $>210 \mathrm{Mt}$ ), Aljustrel ( $>220 \mathrm{Mt})$, Aznalcollar ( $>90 \mathrm{Mt})$, La Zarza $(150 \mathrm{Mt})$, Masa Valverde (100 Mt) and Tharsis (110 Mt).

The La Zarza and Masa Valverde deposits are both located within the watershed of the Odiel River, which flows for $128 \mathrm{~km}$ through southern Spain to join the Tinto River and form a common estuary at the town of Huelva (Fig. 1). The area has a mean annual rainfall of $700 \mathrm{~mm}$ with an effective rainfall of close to $150-225$ $\mathrm{mm}$ (inferred from data recorded during the period 1964-1996). The dry period lasts from April to October.

The host-rock permeability of both deposits is low to very low $\left(10^{-6}\right.$ to $\left.10^{-8} \mathrm{~cm} \mathrm{~s}^{-1}\right)$. Piezometric data were acquired from 38 water points (springs and domestic wells) over an area of about $140 \mathrm{~km}^{2}$ around the La Zarza deposit, and from 54 water points over an area of about $110 \mathrm{~km}^{2}$ around the Masa Valverde deposit. Groundwater circulation occurs at distinct levels: shallow circulation through the porous, low-permeability weathered facies of the VMS volcanic/volcano-sedimentary host rocks and/or sedimentary cover; deeper circulation mainly through fractures and joints. Local flow is subparallel to the topographic surface, whereas deeper regional flow is north to south over a distance of around $50 \mathrm{~km}$ from the Cortegana area (altitude $800 \mathrm{~m}$ ) southwards to the sea.
A high level of contamination in the soils and surface waters has been imparted by mining activities that (a) began in the Chalcolithic era and continued in Roman times (end of the 4th century AD, mainly for copper and silver, and (b) were resumed in the middle of the 19th century with the extraction of pyrite (for sulphuric acid) and base metals (copper) from about 80 mines. Overall, the Iberian Pyrite Belt has produced about $280 \mathrm{Mt}$ of pyrite and base-metal ores, together with significant tonnages of manganese ores.

\subsection{La Zarza}

The La Zarza deposit is primarily a stratiform massive sulphide orebody produced by submarine exhalative deposition. The upper and middle parts of the pyritic orebody are zinc- and lead-rich, whereas the lower part is copper-rich. The massive orebody overlies a feeder stockwork rooted in hydrothermally altered acid volcanics and volcanoclastics. The bulk composition shows the ore to be the characteristic $\mathrm{Zn}-\mathrm{Pb}-\mathrm{Cu}$ type of Phanerozoic VMS associated with a bimodal volcanism. The mined deposit is a continuous lens-shaped body, about $2700 \mathrm{~m}$ long with an $\mathrm{E}-\mathrm{W}$ strike, and is for the most part blind. Its apparent thickness varies from 30 to $200 \mathrm{~m}$ with a minimum downdip extension of $550 \mathrm{~m}$ in the central part (Figs. 2 and 3). This geometry is the result of a system of tight south-verging folds and thrust slices associated with the main phase of D1 synmetamorphic deformation. The deep part of the orebody occupies the hinge of a shear megasyncline with an E-W axis, which is overturned to the south and is accompanied by multiple ductile-brittle shears (thrust slices with a southerly vergence, sinistral transverse thrusts) causing offsets and duplication of the ore layer.

La Zarza, mined between 1853 and 1991, produced $40-45 \mathrm{Mt}$ of pyrite ore (average grade of $47 \% \mathrm{~S}, 0.7 \%$ $\mathrm{Cu}, 1.5 \% \mathrm{Zn}$ and $0.6 \% \mathrm{~Pb}$ ) for sulphur production (Strauss et al., 1981). Precious metals (Au, Ag) are also known to occur. Open-pit mining (in the so-called "Corta San Pablo", etc.) was followed by underground mining that extended for about $2000 \mathrm{~m}$ in an E-W direction, with levels down to $300 \mathrm{~m}$ below the surface. When mining ceased for economic reasons in 1991, the remaining in situ massive sulphide potential at depth was estimated at $110 \mathrm{Mt}$, making it one of the largest known resources in the region. The mine was 


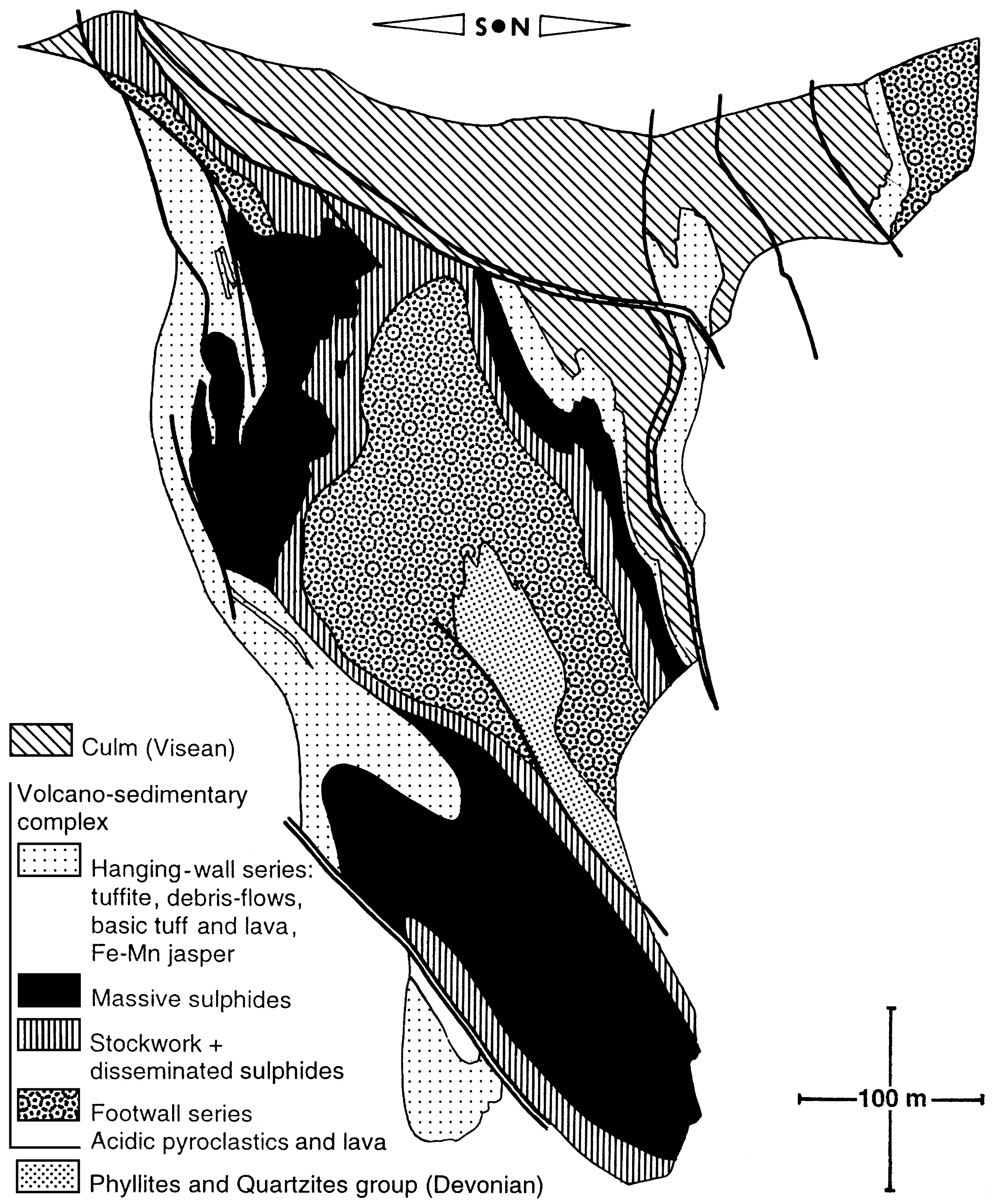

Fig. 2. Cross-section of the La Zarza deposit. 


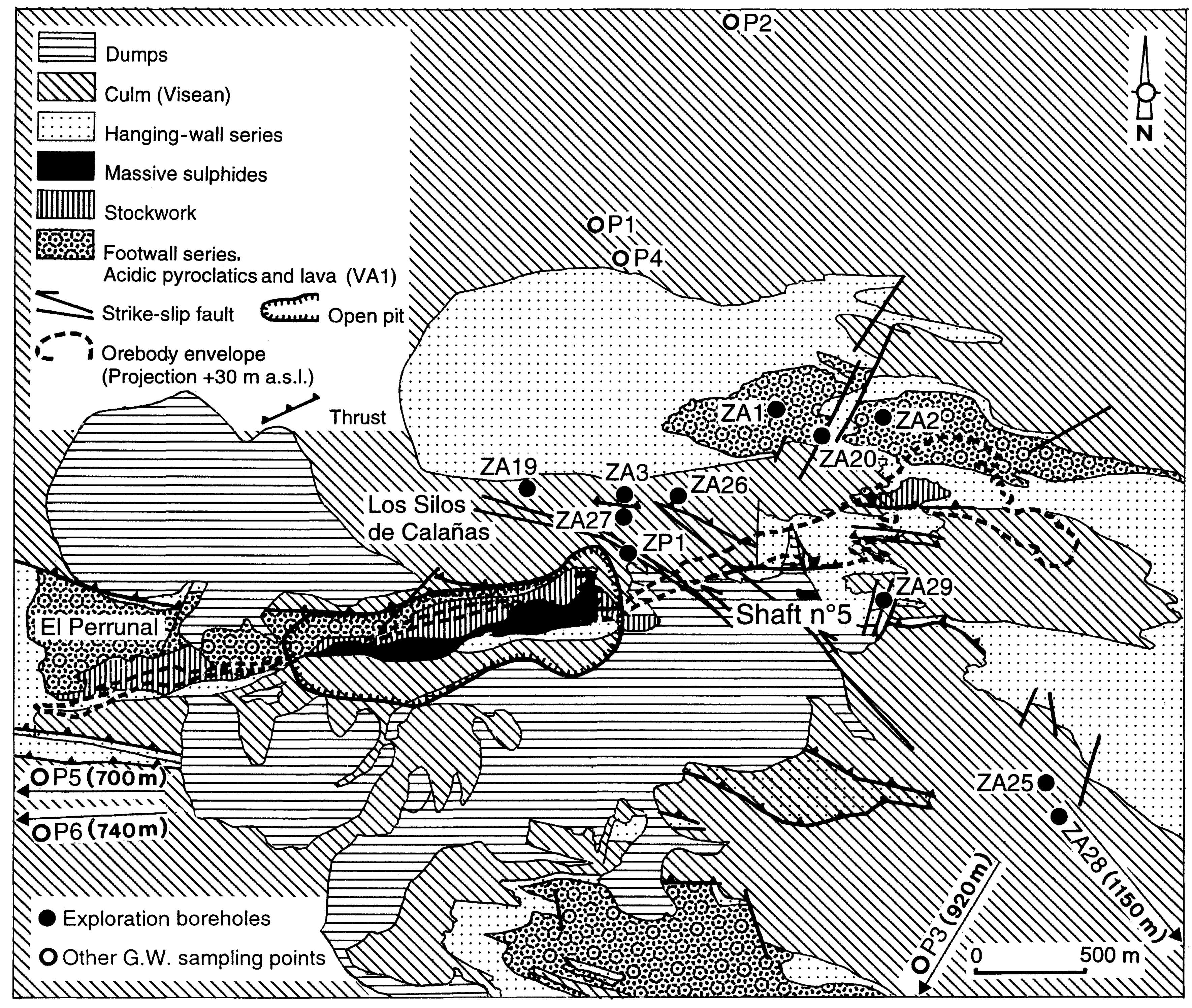

Fig. 3. Simplified geological map of the La Zarza area showing the location of groundwater sampling points. All the plotted exploration boreholes have been sampled. 
maintained until January 1996, when pumping was stopped and the underground workings allowed to flood.

Hydrologically, La Zarza is located in a relatively high topographic area (almost all the exploration borehole collars are between 250 and $280 \mathrm{~m}$ a.s.1.) at the junction of three drainage basins. The piezometric levels reflect the topography, which (a) suggests a predominance of local flow, and (b) indicates that the deposit to be located in an area of hydrogeological recharge.
Compilation of data from the Metallogenic Map of Spain (IGME), aerial photographs, and field campaigns throughout the $140 \mathrm{~km}^{2}$ area around La Zarza, has revealed the presence of several potential contamination sources, including four stratiform polymetallic sulphide deposits, several small manganese deposits, and gossans. Moreover, mining activities at La Zarza have left both old and recent tailings, "morrongos" (calcined sulphides), an old abandoned mine railway, and various shallow exploration shafts and adits.

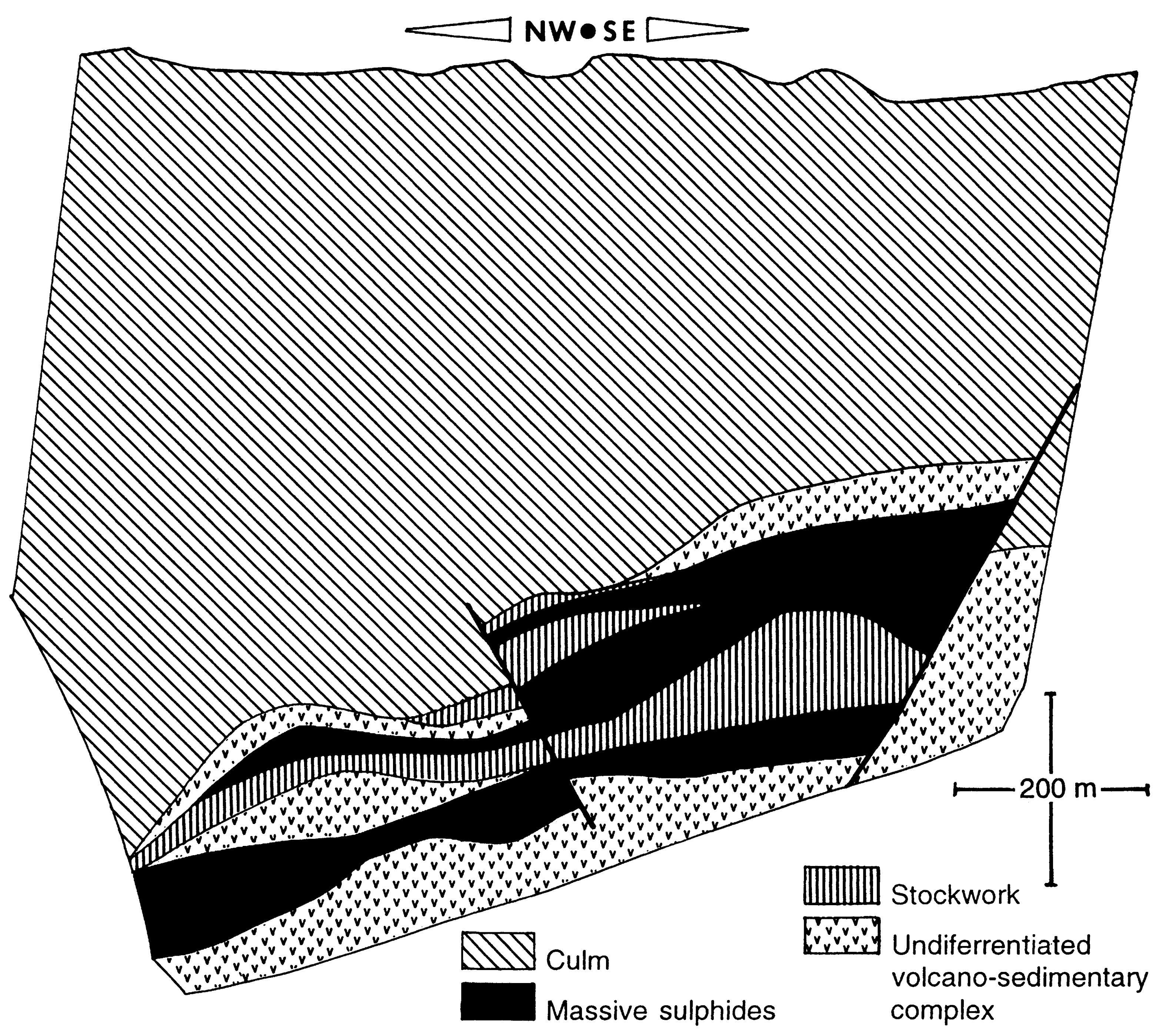

Fig. 4. Cross-section of the Masa Valverde deposit. 


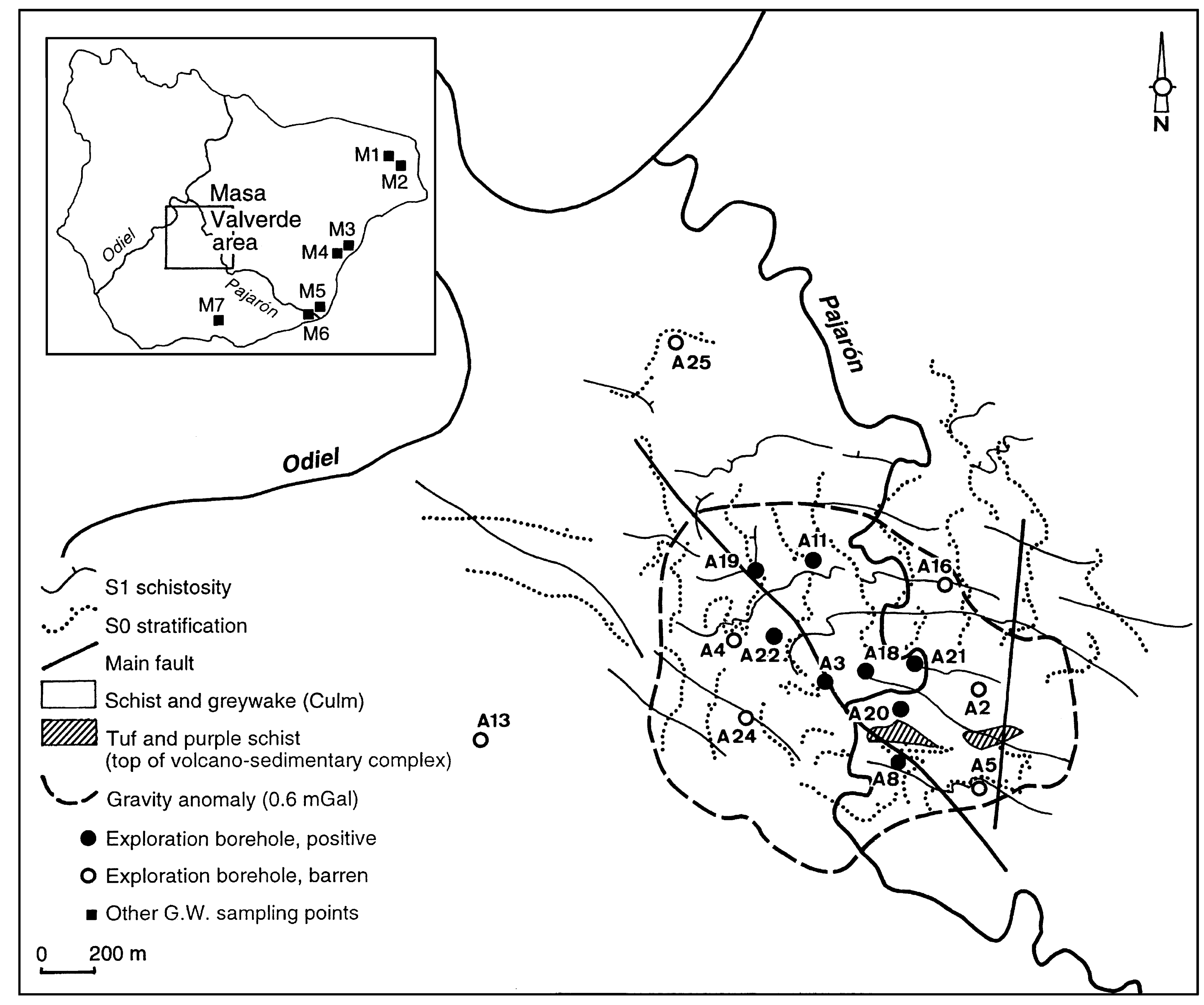

Fig. 5. Location of groundwater sampling points in the Masa Valverde area. All the plotted exploration boreholes have been sampled. 


\subsection{Masa Valverde}

The Masa Valverde deposit, located some $18 \mathrm{~km}$ southwest of La Zarza (Fig. 1), is also a blind submarine VMS orebody comprising some $100 \mathrm{Mt}$ of pyrite and base-metal sulphides. It was discovered in $1985-1986$ by drilling a strong gravity anomaly located over Culm metasediments. The ore is hosted by a strongly deformed volcano-sedimentary sequence of dominant silicic composition and is buried below $400-600 \mathrm{~m}$ of Culm schist and metagreywacke. Information on the geology, lithostratigraphy, geometry and ore composition was obtained from 25 boreholes drilled by Empresa Nacional Adaro de Investigationes, Mineras from 1986.

The regional deformation shows some similarities with La Zarza, although the resulting geometry is different. The deposit structure corresponds to a 500to $600-\mathrm{m}$-deep antiformal stack of slabs bearing stockwork and stratiform massive sulphide bodies, with axes plunging to the northwest. The deposit is cut off at the top by a thrust plane below the Culm metasediments, is terminated to the east and southwest by two high-angle faults (Figs. 4 and 5), and is still open to the north and northeast.

The average composition of the ore is typical of the $\mathrm{Zn}-\mathrm{Pb}-\mathrm{Cu}$ type (Lydon, 1992), i.e. a VMS relatively enriched in $\mathrm{Pb}-\mathrm{Zn}$. The close spatial association between the massive sulphides and stockwork feeders indicates that the deposit was probably proximal. Estimated resources at Masa Valverde, which has not yet been mined, are $100 \mathrm{Mt}$ of mainly pyritic ore containing $0.4 \% \mathrm{Cu}$ and $1.5 \% \mathrm{~Pb}-\mathrm{Zn}$, with some enriched zones of complex ore $(11 \mathrm{Mt}$ at $5 \% \mathrm{Zn}-\mathrm{Pb}$ and $0.54 \%$ $\mathrm{Cu})$ and copper-rich ore $(1.3 \mathrm{Mt}$ at $1.91 \% \mathrm{Cu}$ and $1.7 \%$ $\mathrm{Zn}-\mathrm{Pb}$ ) (Costa and Parilla, 1992).

Hydrologically, the Masa Valverde deposit is in a relatively low topographic area (the exploration borehole collars are between 80 and $160 \mathrm{~m}$ a.s.l.) below the Pajarón River valley and very close to the Odiel River. The piezometric levels do not reflect the surface topography - some wells are even artesian - which suggests that the deposit is located in a discharge zone as well in an area capturing the deep regional flow. Compilation of data from the Metallogenic Map of Spain (IGME), aerial photographs, and field campaigns throughout the $110 \mathrm{~km}^{2}$ area around Masa Valverde, has revealed several potential contamination sources. These include 20 metalliferous occurrences comprising small surface workings of pyrite and polymetallic (copper-rich) veins, and some manganese deposits.

\section{Sampling and analysis}

Three sampling surveys (April 1998, June 1998, and February 1999) were carried out to acquire data on the groundwater chemistry around La Zarza and Masa Valverde (Figs. 3 and 5). During the April and June surveys, groundwater samples were collected from exploration boreholes at both deposits, as well as from two springs and three wells. During the February 1999 survey, groundwater samples were collected only from springs and domestic wells. The 20 water points sampled in the La Zarza area were 11 exploration boreholes, 5 springs and 4 wells, and the 25 water points sampled in the Masa Valverde area were 16 exploration boreholes, 7 domestic wells or boreholes, and 2 points in surface watercourses. In general, the springs, domestic wells and domestic boreholes are located farther from the deposits than the exploration boreholes.

The groundwater was collected with a smalldiameter device that enables samples to be taken at selected depths in exploration boreholes. The device consists of: (1) a 450-m-long Rilsan sampling tube combined with an injection tube, (2) a 40-mm-diameter PVC sampling head equipped with a non-return valve, and (3) a pressurised bottle of neutral gas (nitrogen). Before lowering the sampling head, the tubes are filled with gas at a pressure higher than the hydrostatic pressure at the selected sampling depth so as to prevent premature opening of the valve. Once the head is at the selected depth, the tubes are depressurised to below the hydrostatic pressure whereupon the water to gradually enters the two tubes. The water is then lifted through the sampling tube by injecting gas down the injection tube at a pressure below the sampling depth hydrostatic pressure. A succession of several pressurisation-depressurisation cycles allows the device to be rinsed before each sampling and also facilitates collection of the volume required for the planned analysis. An experiment performed by circulating distilled water through the full 450 -m-length of the device demonstrated the 
absence of significant metallic contamination in the water.

All the groundwater samples were filtered at 0.45 $\mu \mathrm{m}$ and stored either without additives for anion and silica determinations, or acidified to $\mathrm{pH} 2$ with ultrapure $\mathrm{HNO}_{3}$ for major cation and trace-element determinations. Temperature, $\mathrm{pH}, \mathrm{Eh}$, and conductivity were determined on site using Mettler instruments and an Orion $\mathrm{pH}$ electrode with automatic temperature compensation. In addition, 12 profiles of these physico-chemical parameters were run in situ in exploration boreholes using a submersible Idronaut Ocean Seven 302 multiparameter probe. Total alkalinity was also measured on site by titration with $\mathrm{HCl}$, and the equivalent point determined according to Gran (1952). The presence of $\mathrm{H}_{2} \mathrm{~S}$ in the samples was tested by adding a few drops of $\mathrm{Cd}$ acetate and, if a precipitate appeared, determining its concentration by titration with $\mathrm{HgCl}_{2}$.

Major cation ( $\mathrm{Na}, \mathrm{K}, \mathrm{Ca}$ and $\mathrm{Mg}$ ) concentrations were determined by capillary electrophoresis (CIA Waters) with precision ranging from $5 \%$ for concentrations over $2 \mathrm{mg} \mathrm{l}^{-1}$ to $10 \%$ for concentrations between 0.5 and $2 \mathrm{mg} \mathrm{1}^{-1}$. Anion $\left(\mathrm{Cl}, \mathrm{SO}_{4}\right.$ and $\left.\mathrm{NO}_{3}\right)$ concentrations were determined by HPLC (Dionex) with a precision better than $5 \%$. Iron and silica concentrations were determined colorimetrically with a precision of $5 \%$. Total metal concentrations were measured by ICP-MS with detection limits of 0.004 $\mu \mathrm{g} 1^{-1}$ for $\mathrm{Sb}, 0.01 \mu \mathrm{g} \mathrm{l}^{-1}$ for Co and $\mathrm{Mo}, 0.03 \mu \mathrm{g}$ $1^{-1}$ for $\mathrm{Cu}$ and $\mathrm{Cd}, 0.05 \mu \mathrm{g} 1^{-1}$ for $\mathrm{Pb}$ and $\mathrm{Mn}, 0.07$ $\mu \mathrm{g} 1^{-1}$ for As, $0.2 \mu \mathrm{g} 1^{-1}$ for $\mathrm{Al}$, and $0.3 \mu \mathrm{g} 1^{-1}$ for $\mathrm{Ni}$. The analytical precision was $5 \%$ for $\mathrm{Cd}, \mathrm{Pb}$ and $\mathrm{Sb}$, and $10 \%$ for other metals.

Voltammetric measurements of $\mathrm{Cu}, \mathrm{Pb}, \mathrm{Zn}, \mathrm{Cd}$ and Mn trace elements were also performed with the Voltammetric In situ Profiling (VIP) System as described by Tercier-Waeber et al. (1998a). Briefly, the VIP System consists of a submersible voltammetric probe, an Idronaut Ocean Seven 302 multiparameter submersible probe (optional and not used for this project), a calibration deck unit, a surface deck unit and an IBM-compatible PC. The voltammetric probe can be used for in situ measurements down to a depth of $500 \mathrm{~m}$, with data being transferred by telemetry. The standard design of the VIP voltammetric probe was modified for our specific application; specifically, the Delrin housing was replaced by a titanium housing, the diameter was reduced from 100 to $75 \mathrm{~mm}$, and pressure and temperature sensors were incorporated in the probe. The heart of the probe is an Agarose Membrane-covered mercury-plated Ir-based microelectrode used either singly or in array (as for this project). It is integrated, together with an auxiliary and reference electrodes, in a pressure-compensated flow-through cell. These sensors present important advantages for in situ trace-metal measurements in natural waters (Belmont-Hébert et al., 1998; TercierWaeber et al., 1998b). In particular, the voltammetric signals measured at micro-sized electrodes are directly proportional to the concentration of the mobile fraction of trace metals (defined as free metal ions and small labile complexes with sizes less than a few nanometers). In addition, organic and inorganic colloidal and particulate materials are efficiently excluded from the agarose gel and do not interfere with the voltammetric measurements (i.e., fouling problem is avoided). The first point is important because the trace-element mobile fraction is the fraction that is most easily bioavailable, and thus is the fraction required for ecotoxicological assessment. Moreover, due to sample degradation, plus the risk of contamination during sample storage and separation procedures, etc., the mobile fraction is difficult to measure without analytical artefact when using classical techniques; it thus requires direct in situ measurement. Management software allows the user to control and configure the voltammetric probe operating parameters and functions, such as electrochemical parameters, data acquisition, calibration and maintenance operations.

During the April 1998 sampling survey, eight water samples were collected from four boreholes. After filtration, the samples were stored at a temperature of less than $+4 \circ \mathrm{C}$ without any additives and sent to the University of Geneva for laboratory voltammetric analyses using the VIP System; this being the first attempt to measure metal concentrations in groundwater with the VIP, it was necessary to ensure that a signal would be obtained. During the June 1998 sampling survey, voltammetric measurements were performed in the field. With three holes, the VIP probe was lowered directly into the holes and the measurements made in situ. For two other holes, where the 56-mm internal diameter was too small for the probe, the input of the VIP voltammetric flow- 
through cell was connected to the outlet of the water sampling device, and measurement occurred merely a few minutes after the groundwater had circulated from the sampler to the probe without any contact with the atmosphere-five samples were analysed in this way. The detection limits with the VIP System were 5, 10, 15 , and $25 \mathrm{ng} 1^{-1}$ for $\mathrm{Cd}, \mathrm{Pb}, \mathrm{Cu}$ and $\mathrm{Zn}$, respectively, and $50 \mu \mathrm{g} \mathrm{I}^{-1}$ for $\mathrm{Mn}$.

\section{Results}

\subsection{Physico-chemical parameters and major-element concentrations in groundwater at the La Zarza and Masa Valverde deposits}

Groundwater at the La Zarza and Masa Valverde deposits displayed wide variations in composition, both with depth and between different boreholes. This is demonstrated in Fig. 6, where the physico-chemical parameter profiles show very strong variations that are consistent with water-rock interactions in a fracturedominated flow system. In the case of La Zarza, the data is also consistent with modified water-rock interactions due to the presence of cavities related to previous mining. Variations in the major-element concentrations were also observed as a function of depth and, more significantly, between boreholes. For example, $\mathrm{Cl}$ concentration in the La Zarza groundwater varies laterally between 10 and $155 \mathrm{mg}^{-1}$, whereas variability with depth accounts for less than $10 \mathrm{mg} \mathrm{l}^{-1}$.

The physico-chemical parameters indicate important differences between the groundwater at the two deposits. The La Zarza groundwater, with Eh between -30 and $+400 \mathrm{mV}$ (one point of $+600 \mathrm{mV}$ was even measured), is oxidizing whereas the Masa Valverde groundwater, with Eh between -285 and $-230 \mathrm{mV}$, is highly reducing. The groundwater $\mathrm{pH}$ also shows differences between the two deposits; the
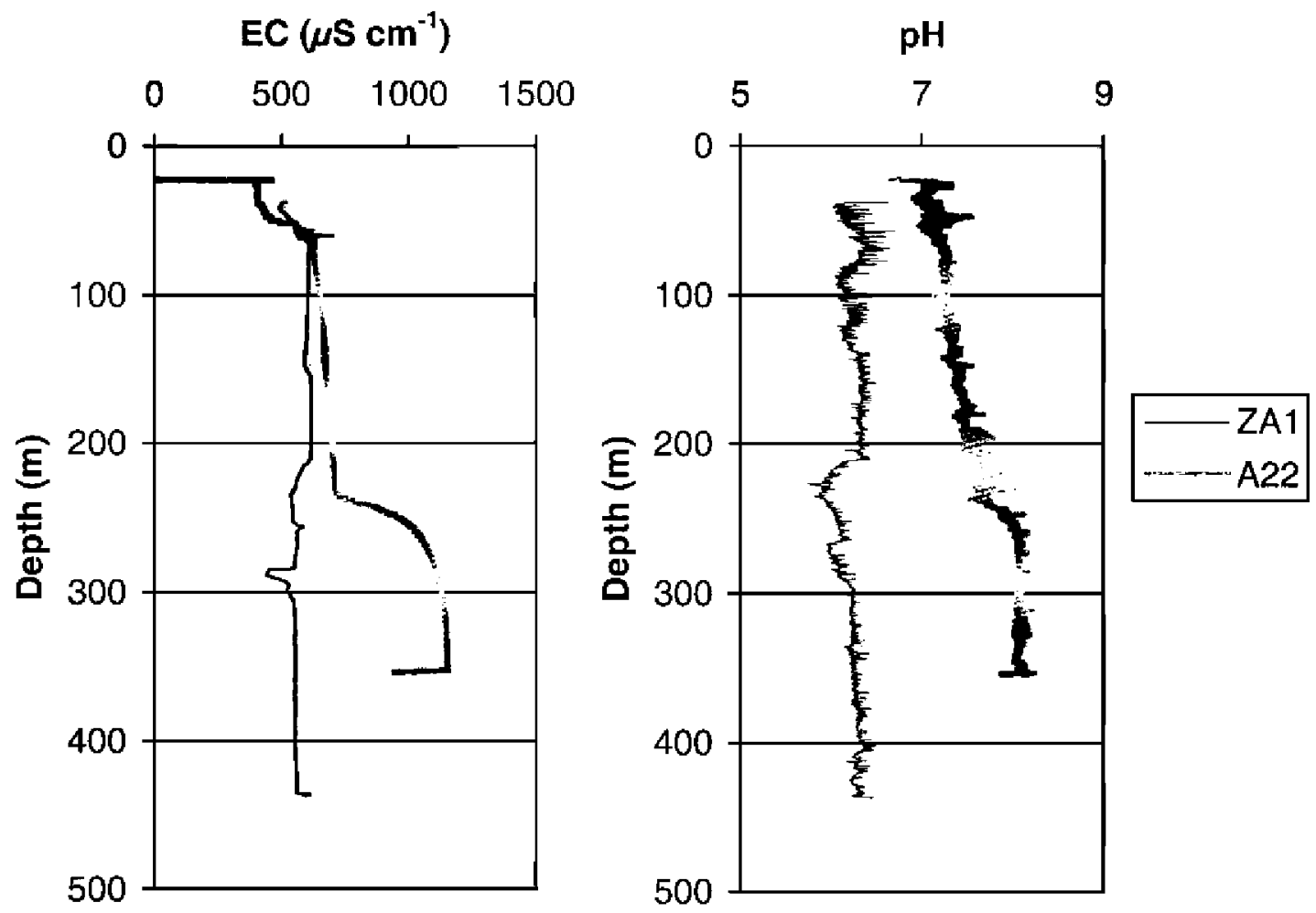

Fig. 6. Selected $\mathrm{pH}$ and electrical conductivity profiles obtained in exploration boreholes with the Idronaut Ocean Seven 302 probe. Examples from boreholes ZA1 (La Zarza) and A22 (Masa Valverde). 
La Zarza groundwater, with a $\mathrm{pH}$ between 6.38 and 7.95 (average 6.82) apart from one point at $\mathrm{pH} 3.28$, is more acid than the Masa Valverde groundwater, with a $\mathrm{pH}$ ranging between 6.45 and 8.46 (average 7.71).

Although groundwater conductivity is similar at the two deposits, with variations between 530 and $1200 \mu \mathrm{S} \mathrm{cm}^{-1}$ (average $735 \mu \mathrm{S} \mathrm{cm}{ }^{-1}$ ) at La Zarza and between 125 and $1125 \mu \mathrm{S} \mathrm{cm}{ }^{-1}$ (average $678 \mu \mathrm{S}$ $\mathrm{cm}^{-1}$ ) at Masa Valverde, one finds differences in the major cation and anion contents. The Masa Valverde groundwater is bicarbonate dominated, with higher $\mathrm{Na}-\mathrm{K}$ and lower $\mathrm{Ca}-\mathrm{Mg}$ than the La Zarza groundwater (Fig. 7a and b). The relative proportion of cations is more variable at Masa Valverde than at $\mathrm{La}$ Zarza, whereas the relative proportion of anions is more variable at La Zarza than at Masa Valverde. This variation is related mainly to sulphate concentrations. The Masa Valverde groundwater, despite the sulphidic nature of the ore, shows low sulphate concentrations (some samples were even below the detection limit of $0.1 \mathrm{mg} 1^{-1}$ ), as opposed to the La Zarza groundwater, which contains significant sulphate concentrations.

As regards $\mathrm{H}_{2} \mathrm{~S}$ concentration in the groundwater, this was determined in two boreholes at the La Zarza deposit- 0.5 to $1.3 \mathrm{mg}^{-1}$ in ZA2, and traces too low for analysis in ZA28-but was below the detection limit in all groundwater samples from the Masa Valverde deposit.

\subsection{Waters sampled away from the main ore zones}

Groundwater sampled from springs and domestic wells away from the deposits yielded $\mathrm{pH}$ values between 6.4 and 7.9 and Eh values in the range of $+200-360 \mathrm{mV}$. These values are closer to those of the La Zarza groundwater than the Masa Valverde groundwater. Similarly, the relative major cation and anion concentration patterns in the spring and well groundwater are similar to those of the La Zarza groundwater, with sulphate concentrations between 15 and $500 \mathrm{mg} \mathrm{l}^{-1}$ and a relative proportion of alkali earth elements $(\mathrm{Ca}-\mathrm{Mg})$ higher than the alkaline ions $(\mathrm{Na}-\mathrm{K})$. A water sample taken from the Odiel River, just below its confluence with the Pajaron River, yielded a very low $\mathrm{pH}$ and high dissolved-element concentrations (Table 1), which agrees with other measurements performed in this stream (Nelson and
Lamothe, 1993; Elbaz-Poulichet and Dupuy, 1999). Such extremely acid and metal-rich water, which is also reported from other streams in the area such as the Rio Tinto (Elbaz-Poulichet and Leblanc, 1969), results from intensive pollution due to sulphide-mineral oxidation.

\subsection{Metal concentrations in the groundwater}

Most of the samples analysed by ICP-MS showed detectable total-metal concentrations that varied both with depth and laterally between boreholes. The measured concentrations for all the metals ranged through more than two orders of magnitude and, for any given borehole, the variability of some metal concentrations was as high as a single order of magnitude (e.g., As and $\mathrm{Ni}$ in La Zarza borehole ZA3 ranged from 2 to 25 $\mathrm{mg} 1^{-2}$ and from 2 to $11 \mu \mathrm{g} 1^{-1}$, respectively).

The concentration range for $\mathrm{Z}(\mathrm{Zn}+\mathrm{Cu}+\mathrm{Pb}+\mathrm{C}$ $+\mathrm{Cd}+\mathrm{As}+\mathrm{Ni}+\mathrm{Co}$ ) was found to be of a same order of magnitude for all the groundwater, whether at $\mathrm{La}$ Zarza or at Masa Valverde, or away from the deposits (Fig. 8). A similar situation was also observed for the individual metals - the groundwater concentration range of each metal was similar regardless of the provenance of the groundwater. Thus, it was impossible, on the basis of a particular metal, to distinguish groundwater from the vicinity of a specific deposit from groundwater of another deposit or even from groundwater distant from a deposit (Fig. 9).

Comparison between total metal concentration in the La Zarza groundwater and the mean composition of the La Zarza ore (Fig. 9) shows clearly that, for all metals except $\mathrm{Ni}$, the measured groundwater concentrations are below those to be expected from stoichiometric dissolution. In other words, the groundwater metal concentrations are lower than expected from sulphates if one assumes that all sulphide minerals are oxidized at the same rate and with no subsequent precipitation. A major exception at La Zarza is the groundwater from borehole ZA20, which is characterised by a low $\mathrm{pH}$.

\subsection{Comparison of the VIP and ICP-MS results}

Comparison between the metal concentrations determined with the VIP System and those determined by ICP-MS was possible for 15 of the groundwater 

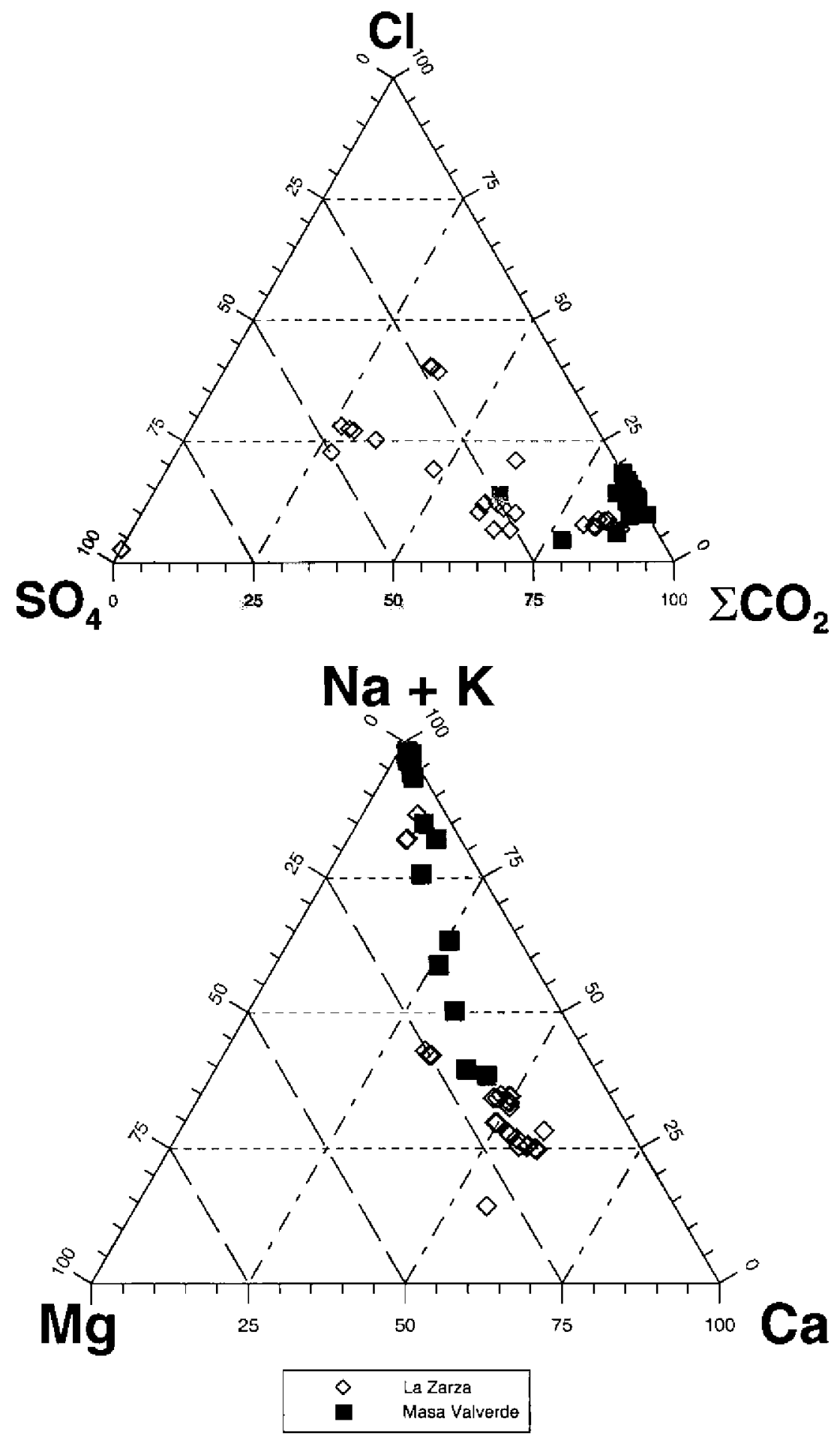

Fig. 7. Relative proportions of (A) $\mathrm{Cl}, \mathrm{H}_{2} \mathrm{CO}_{3}+\mathrm{HCO}_{3}\left(? \mathrm{CO}_{2}\right), \mathrm{SO}_{4}$, and (B) $\mathrm{Na}+\mathrm{K}, \mathrm{Ca}$ and $\mathrm{Mg}$ in groundwater at the $\mathrm{La}$ Zarza and Masa Valverde deposits. 
Table 1

Chemical compositions of selected groundwater sampling points at and away from the La Zarza and Masa Valverde deposits

\begin{tabular}{|c|c|c|c|c|c|c|c|c|c|c|c|c|c|c|c|c|c|c|c|c|c|}
\hline \multirow[t]{2}{*}{ Hole } & \multicolumn{13}{|c|}{ La Zarza } & \multicolumn{8}{|c|}{ Masa Valverde } \\
\hline & $\mathrm{ZA} 2$ & & & & & $\mathrm{ZA} 3$ & & & & ZA20 & ZA26 & $\mathrm{P} 4$ & P6 & A4 & A 8 & A13 & A18 & A19 & A25 & M5 & Odiel \\
\hline Depth (m) & 61.5 & 190 & 286 & 324 & 368 & 200 & 245 & 270 & 430 & 40 & 65 & & & 140 & 111 & 140 & 140 & 140 & 140 & & \\
\hline $\mathrm{pH}$ & 7.21 & 6.95 & 6.96 & 6.99 & 6.97 & 6.59 & 6.61 & 6.62 & 6.62 & 3.28 & 6.79 & 7 & 6.94 & 8.35 & 6.45 & 7.09 & 8.26 & 7.99 & 8.06 & 6.9 & 3 \\
\hline $\mathrm{Eh}(\mathrm{mV})$ & -32 & -38 & -36 & -74 & 86 & 259 & 363 & 416 & 180 & 602 & 298 & na & 367 & -280 & -228 & -245 & -278 & -265 & -275 & & \\
\hline $\mathrm{EC}\left(\mu \mathrm{S} \mathrm{cm}{ }^{-1}\right)$ & 599 & 545 & 541 & 614 & 607 & 1005 & 1008 & 1000 & 978 & 721 & 1188 & na & 1180 & 727 & 124 & 484 & 967 & 922 & 1125 & na & na \\
\hline Alk (meq $\left.1^{-1}\right)$ & 5.72 & 5.8 & 5.84 & 5.45 & 5.37 & 2.05 & 2.23 & 2.38 & 3.06 & nd & 2.94 & na & na & 7.99 & 0.71 & 5.34 & 7.53 & 7.49 & 9.1 & na & na \\
\hline $\mathrm{Na}\left(\mathrm{mg} 1^{-1}\right)$ & 29.5 & 27.9 & 27.8 & 30.3 & 29.1 & 57.2 & 57.1 & 57.7 & 57.8 & 9.5 & 86.9 & 47.6 & 61.7 & 68.4 & 16.4 & 91.3 & 269 & 230 & 302 & 42.4 & 21.7 \\
\hline K & 4.3 & 4.8 & 5 & 4.7 & 4.2 & 1.3 & 1.2 & 1.2 & nd & 1.2 & 1.6 & nd & 7.1 & 1.4 & 1.1 & 13.5 & 2.7 & 2.3 & 3.2 & 2.3 & 3.2 \\
\hline $\mathrm{Ca}$ & 74.1 & 73.4 & 72.8 & 81.9 & 79.1 & 97.3 & 97.5 & 98.6 & 117.2 & 41.9 & 123 & 75.8 & 157 & 71 & 7 & 20.5 & 6.6 & 11.5 & 3.8 & 126 & 144 \\
\hline $\mathrm{Mg}$ & 25.6 & 23.2 & 22.6 & 23.7 & 22.4 & 40.9 & 40.6 & 40.5 & 40.6 & 22.4 & 46.9 & 30 & 68.2 & 36 & 3.1 & 13.1 & 2.7 & 4.7 & 1.2 & 63.8 & 124 \\
\hline $\mathrm{Cl}$ & 22.4 & 31.5 & 30.7 & 34.1 & 33.7 & 133 & 133 & 135 & 139 & 9 & 149 & 73.9 & 59.6 & 32.7 & 9.8 & 34.8 & 102 & 92.2 & 126 & 26 & 23 \\
\hline $\mathrm{SO}_{4}$ & 53.8 & 46.3 & 45.1 & 32.8 & 29.2 & 214 & 213 & 217 & 223 & 318 & 327 & 116 & 480.2 & 41.4 & 16.9 & nd & nd & nd & nd & 559 & 1320 \\
\hline $\mathrm{H}_{2} \mathrm{~S}$ & 1.34 & 0.82 & 0.54 & 0.54 & 0.54 & nd & nd & nd & nd & nd & nd & nd & nd & nd & nd & nd & nd & nd & nd & nd & nd \\
\hline $\mathrm{Si}$ & 12.2 & 11.8 & 11.7 & 12.6 & 12 & 8.9 & 8.8 & 8.7 & 8.6 & 13.4 & 8.9 & na & 9.2 & 9.8 & 5.6 & 5.4 & 7.6 & 7.8 & 8.6 & na & na \\
\hline $\mathrm{Fe}$ & nd & 0.04 & nd & nd & 0.05 & 0.05 & 0.12 & nd & 1.73 & 30.6 & 0.29 & na & 0.13 & 0.1 & 1.6 & 3.68 & 0.01 & 0.32 & 0.11 & na & na \\
\hline $\operatorname{Mn}\left(\mu g 1^{-1}\right)$ & 1017 & 973 & 950 & 905 & 891 & 2571 & 2436 & 2377 & 2442 & 3094 & 3500 & 830 & 20.8 & 279 & 270 & 587 & 9.1 & 114 & 18.9 & 1705 & 0.53 \\
\hline $\mathrm{Zn}$ & 3 & 1.4 & 0.9 & 6.1 & 1.7 & 45.3 & 40 & 57.9 & 20.3 & 2313 & 28.1 & 2.8 & 18.3 & 12 & 5.88 & 8 & 4 & 2.3 & 5.3 & 11.7 & 21618 \\
\hline $\mathrm{Cd}$ & 0.04 & 0.001 & 0 & 0.04 & 0.001 & 0.29 & 1.2 & 0.69 & 0.03 & 10.1 & 0.17 & nd & 0.093 & nd & 0.05 & nd & nd & nd & 0.05 & 0.005 & 102 \\
\hline $\mathrm{Pb}$ & 0.25 & 0.27 & 0.22 & 0.19 & 0.1 & 0.29 & 0.45 & 0.26 & 0.14 & 454 & 0.22 & nd & 0.16 & 0.14 & 0.42 & 0.29 & 2 & 0.29 & 1.5 & 0.13 & 156 \\
\hline $\mathrm{Co}$ & 0.3 & 0.27 & 0.31 & 0.32 & 0.26 & 7.6 & 7.5 & 7.8 & 0.6 & 34.8 & 3.9 & 2.62 & 0.14 & 0.84 & 0.99 & 0.31 & 0.03 & 0.16 & 0.06 & 0.74 & 533 \\
\hline $\mathrm{Ni}$ & 2.1 & 1.9 & 2 & 2 & 1.6 & 10.9 & 10.6 & 9.8 & 2.1 & 22.8 & 6.6 & 6.49 & 1.6 & 2 & 4 & 1.7 & 0.2 & 0.4 & 0.4 & 4.3 & 268 \\
\hline As & 11 & 8.5 & 8.2 & 18 & 11.9 & 2.5 & 2.2 & 2 & 25.4 & 7.2 & na & 1.02 & na & 0.27 & na & 0.4 & 1.7 & 1.1 & 0.86 & 1.49 & 7.96 \\
\hline Mo & 0.69 & na & na & na & na & na & na & na & na & na & na & na & na & na & 0.29 & na & na & na & na & na & na \\
\hline $\mathrm{Sb}$ & 0.12 & na & na & na & na & na & na & na & na & na & na & na & na & na & 0.06 & na & na & na & na & na & na \\
\hline
\end{tabular}

n.d.: not detected; n.a.: not analysed. 


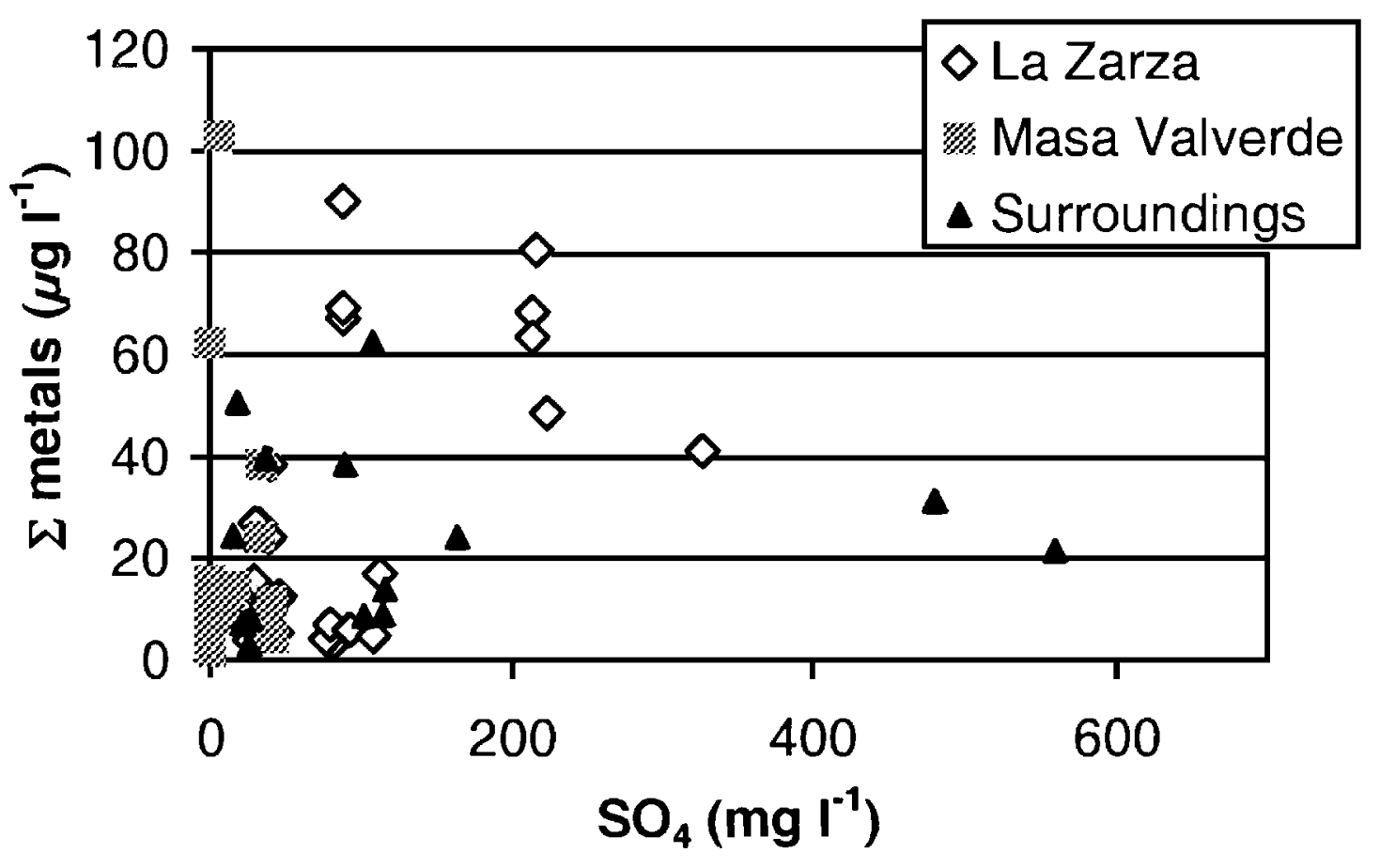

Fig. 8. The $\mathrm{Z}(\mathrm{Zn}+\mathrm{Cu}+\mathrm{Pb}+\mathrm{Cd}+\mathrm{As}+\mathrm{Ni}+\mathrm{Co})$ versus $\mathrm{SO}_{4}$ concentration in groundwater at the La Zarza and Masa Valverde deposits.

samples (Fig. 10) - 13 samples for $\mathrm{Cu}, \mathrm{Pb}, \mathrm{Zn}$ and $\mathrm{Cd}$ (one of these also for $\mathrm{Mn}$ ) from the La Zarza deposit, and 2 samples for Mn at the Masa Valverde deposit.

Copper was detected by the VIP System in two of the samples, but at concentrations representing only $5.8 \%$ and $6.1 \%$ of the values determined by ICP-MS.
The VIP System detection limit for $\mathrm{Cu}$ being $15 \mathrm{ng}$ $1^{-1}$, it can be estimated that the mobile fractions of $\mathrm{Cu}$ for the other samples were less than $3 \%$ of the $\mathrm{Cu}$ total concentrations determined by ICP-MS.

Zinc was detected by the VIP System in all samples except two from La Zarza borehole ZA28. The concentrations of the mobile $\mathrm{Zn}$ species represented 0.5$21 \%$ (average $7.9 \%$ ) of the total $\mathrm{Zn}$ concentrations determined by ICP-MS. The lack of detectable $\mathrm{Zn}$ in borehole ZA28 samples indicates that the amount of the mobile $\mathrm{Zn}$ species at this site was less than $0.5 \%$ of the total $\mathrm{Zn}$ concentrations determined by ICP-MS.

Cadmium, when detected by the VIP System, represented $7.5-27 \%$ (average 14\%) of the total $\mathrm{Cd}$ concentrations determined by ICP-MS. When no mobile $\mathrm{Cd}$ species was detected, it accounted for less than $1 \%$ of that determined by ICP-MS.

Lead was detected in all samples by the VIP System, with the concentrations of the mobile $\mathrm{Pb}$ species representing $8-100 \%$ (average $67 \%$ ) of the total $\mathrm{Pb}$ concentration measured by ICP-MS.
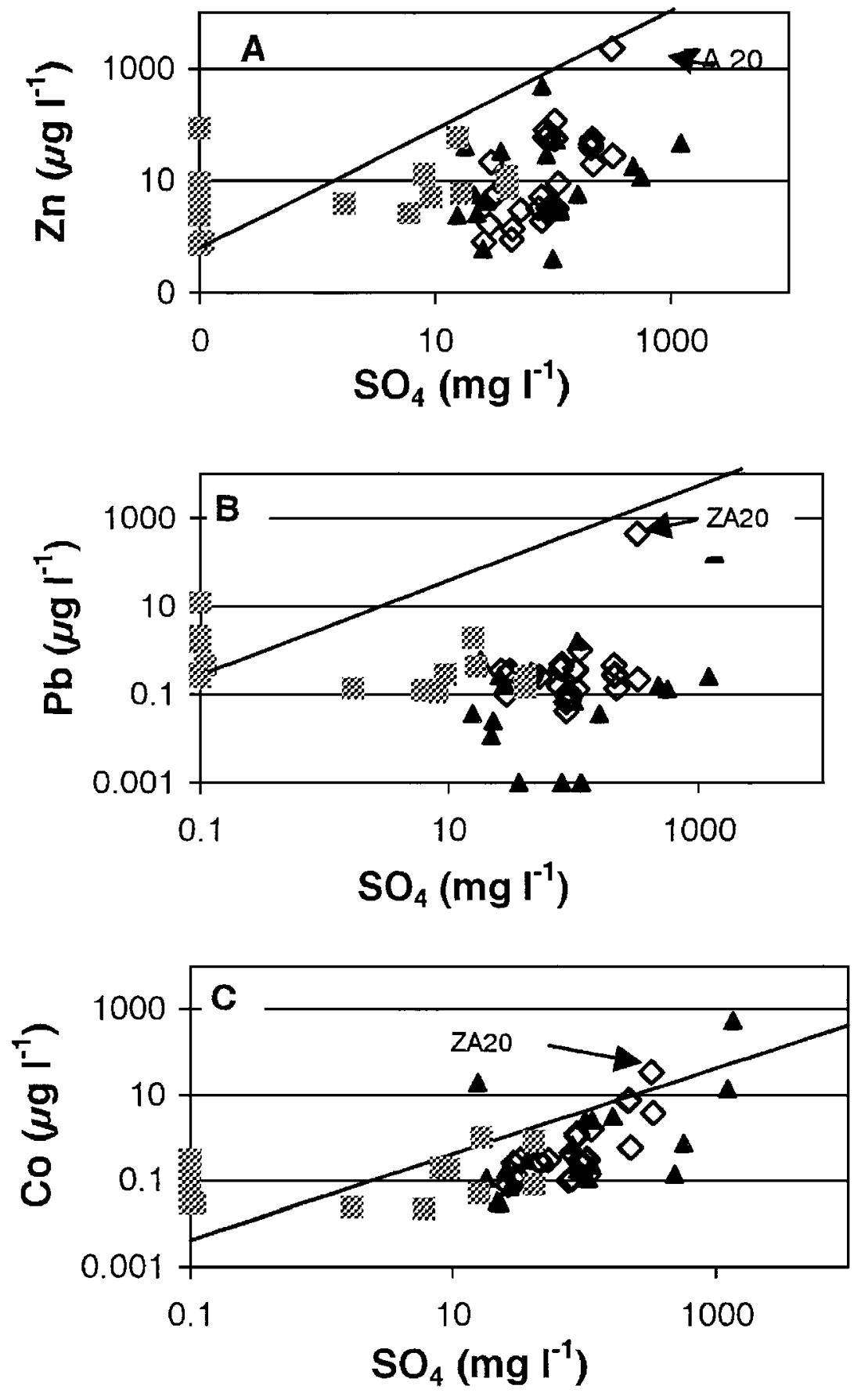
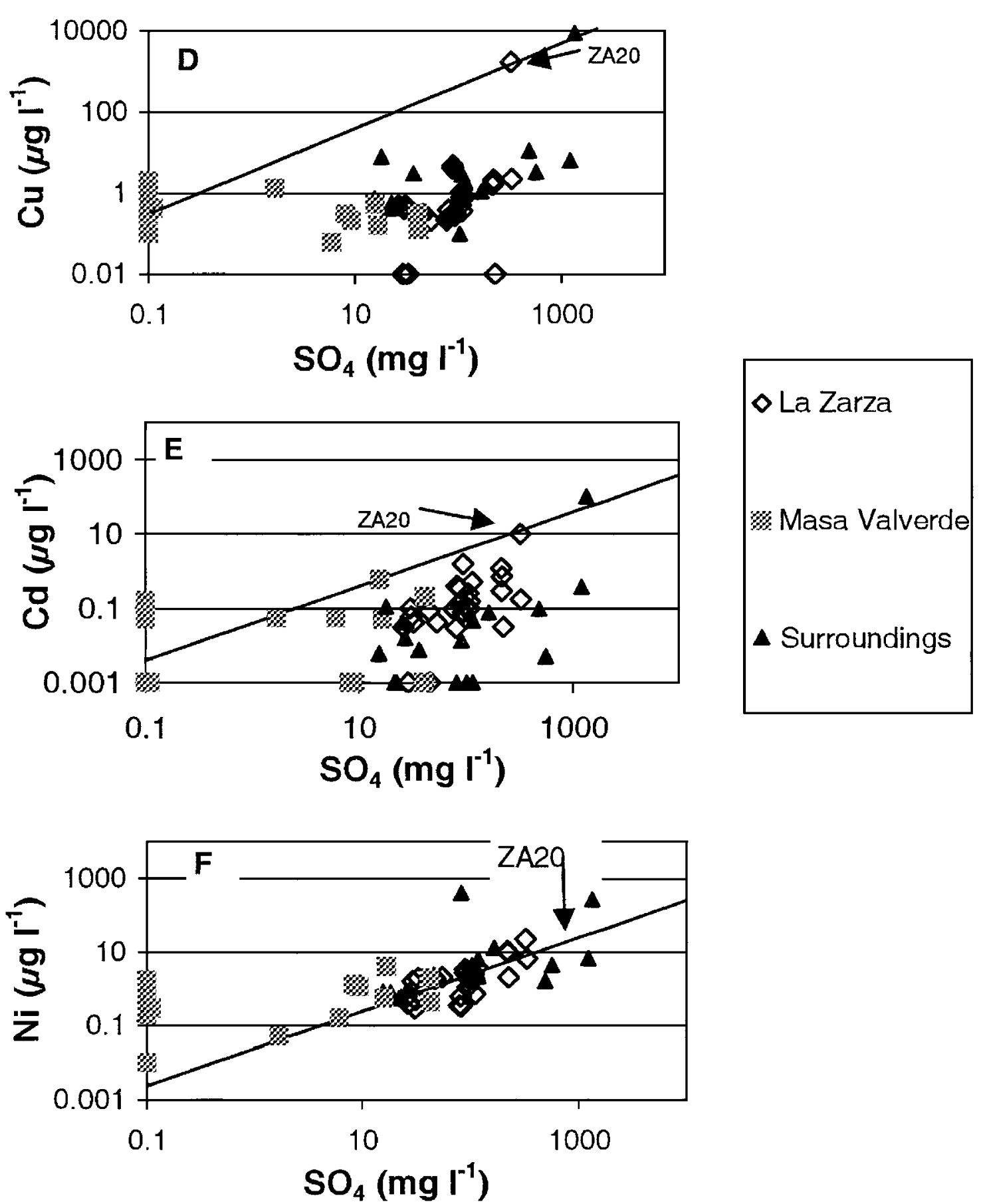

Fig. 9. (Metal, $\mathrm{SO}_{4}$ ) diagrams: (A) $\mathrm{Zn},(\mathrm{B}) \mathrm{Pb},(\mathrm{C}) \mathrm{Co},(\mathrm{D}) \mathrm{Cu},(\mathrm{E})(\mathrm{Cd},(\mathrm{F}) \mathrm{Ni}$. Lines on each diagram represent stoichiometric dissolution of the La Zarza ore calculated from the bulk sulphides composition (S: 30.14\%; Zn: 1.15\%; Cu: 0.73\%; Pb: 0.54\%; Cd: 55 ppm; Co: 60 ppm; Ni: 20 ppm). 

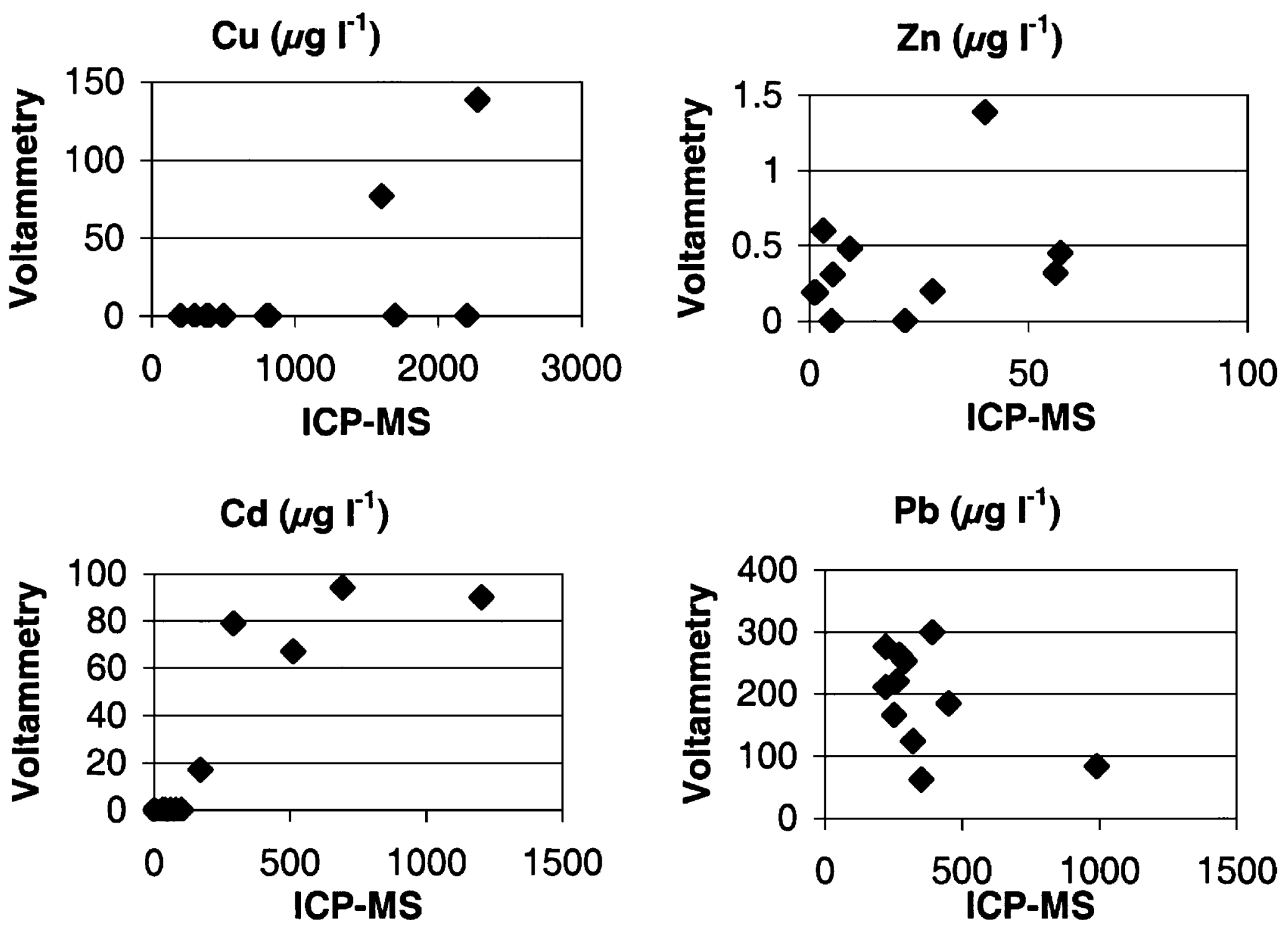

Fig. 10. VIP System versus ICP-MS determinations for $\mathrm{Cu}, \mathrm{Zn}, \mathrm{Cd}$ and $\mathrm{Pb}$ concentrations in groundwater at the La Zarza deposit.

Manganese data is limited to only three samples (one from La Zarza and two from Masa Valverde) analysed by both the VIP System and ICP-MS. The mobile Mn concentrations determined by the VIP System represented 100\% (La Zarza) and 64\% (Masa Valverde) of the total Mn concentration determined by ICP-MS.

These percentages provide interesting information regarding the nature of the metals in the groundwater. They clearly indicate that the $\mathrm{Cu}, \mathrm{Cd}$ and $\mathrm{Zn}$ mobile fractions (free ions and small labile complexes of $<4$ $\mathrm{nm}$, including inorganic complexes such as hydroxides, chlorides, carbonates or sulphates) represent only a small fraction of the total metal concentrations. $\mathrm{The} \mathrm{Pb}$ and $\mathrm{Mn}$ mobile fractions, however, are more significant.

\section{Discussion}

\subsection{Chemical and hydrological differences between La Zarza and Masa Valverde groundwater}

As stated earlier, groundwater from the La Zarza deposit and groundwater from Masa Valverde deposit show differences in chemical composition, particularly as regards $\mathrm{pH}$, redox conditions and relative proportions of major cations and anions. This difference is illustrated clearly by comparison of the $\mathrm{Na} / \mathrm{Cl}$ ratios (Fig. 11A). The Masa Valverde deposit data show a strong correlation $\left(R^{2}=0.94\right)$ between $\mathrm{Na}$ and $\mathrm{Cl}$, which differs from the equivalent correlation $\left(R^{2}=0.80\right)$ given by the La Zarza deposit data (excepting borehole ZA28). This suggests that the groundwater chemical compositions result from mixing trends between a $(\mathrm{Na}+\mathrm{Cl})$-depleted end-member and two different $(\mathrm{Na}+\mathrm{Cl})$-rich end-members.

One hypothesis for the nature of the dilute endmember is simply that of a shallow flow subsequent to rainfall. In the case of Masa Valverde, this hypothesis is strengthened by the presence of $\mathrm{SO}_{4}$ above the limit of detection in the groundwater samples with the lower $\mathrm{Na}$ and $\mathrm{Cl}$ concentrations (Fig. 11B), indicating that the dilute end-member contains oxygen that could cause oxidation of the sulphide minerals. The $\mathrm{SO}_{4}$ concentration would then indicate low oxygen consumption by soil respiration and thus rapid circulation of the water, such as can occur locally through faults (or possibly through a deficient well cementation, considering that exploration boreholes do not require the same finish as hydrological wells).

Further geochemical analysis, including isotopic investigations, would be necessary to fully explain the origin of the salinity of each $(\mathrm{Na}+\mathrm{Cl})$-rich end- 

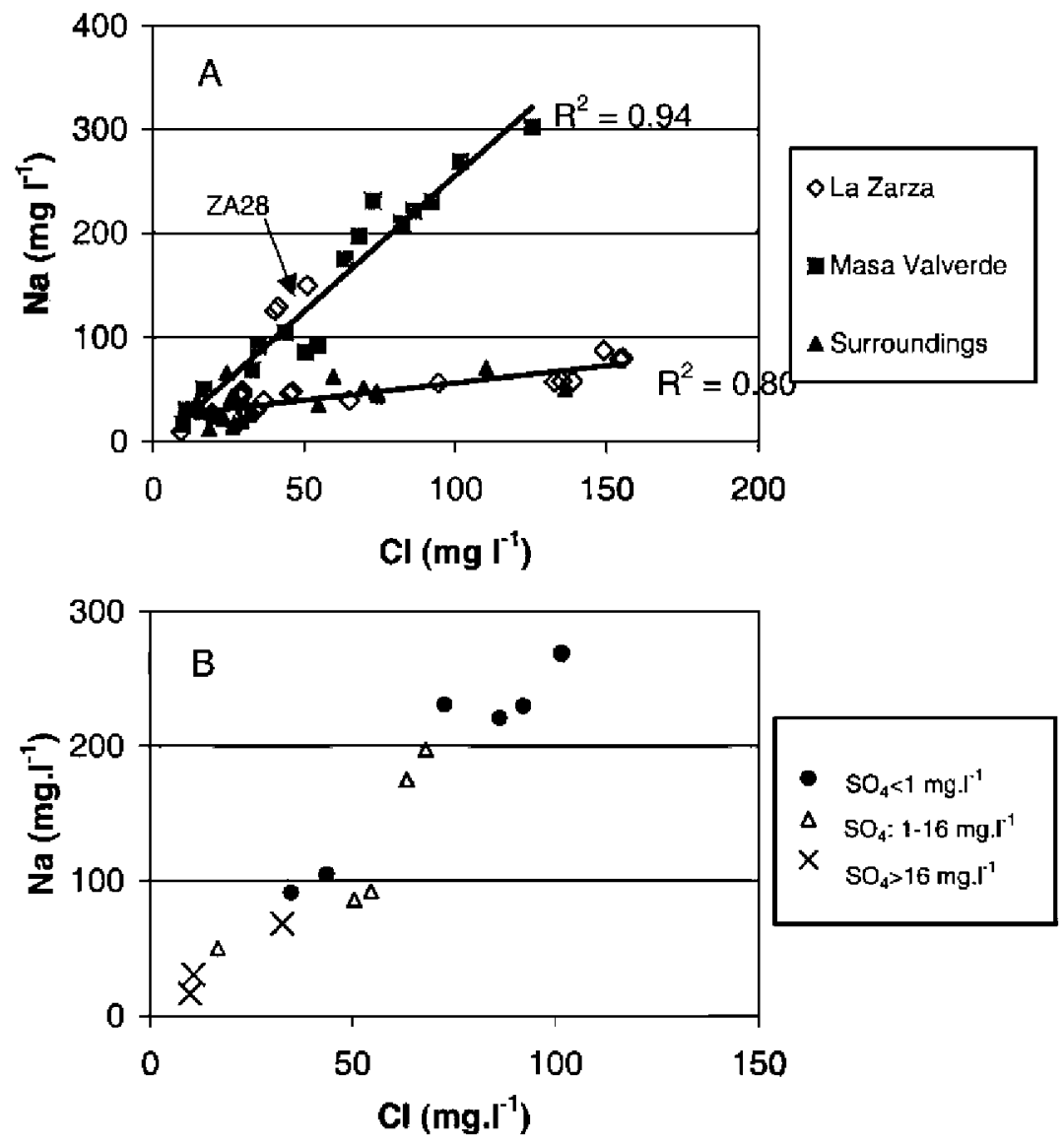

Fig. 11. Na versus $\mathrm{Cl}$ concentration in groundwater (A) at the La Zarza and Masa Valverde deposits, and away from these deposits, (B) at the Masa Valverde deposit. The size of the circles relates to the $\mathrm{SO}_{4}$ concentration.

member. However, the presence of two distinct $(\mathrm{Na}+\mathrm{Cl})$-rich end-members is in accordance with the hydrogeological observations. In particular, the piezometric level at La Zarza indicates a predominance of local flow, whereas at Masa Valverde it reveals the occurrence of deeper flow. This concept is strengthened by the redox and $\mathrm{pH}$ data that suggest interaction of an $\mathrm{O}_{2}$-free water with the sulphide deposit. In other words, when the deep groundwater with the $(\mathrm{Na}+\mathrm{Cl})$-rich end-member composition reaches the Masa Valverde deposit, the dissolved electron acceptors have been consumed, probably through the oxidation of dissolved or solid organic matter present in both water and rock, and consequently part of the waters are $\mathrm{SO}_{4}$-free despite interactions with the sulphide deposit.
Data from La Zarza borehole ZA28, which plots on the Masa Valverde mixing line, also accords with the above hypothesis. This borehole, $2.4 \mathrm{~km}$ southeast of the La Zarza deposit, is in a relatively depressed topographically and is slightly artesian. It is probably these differences in the hydrogeological conditions, with respect to the other La Zarza exploration boreholes, that explain the deep flow chemical signature of ZA28 groundwater.

Whatever the origin of the two $(\mathrm{Na}+\mathrm{Cl})$-rich endmembers, they appear to form a significant part of the IPB groundwater because (1) the composition of the ZA28 groundwater to the southeast of the La Zarza deposit plots on the Masa Valverde groundwater trend, and (2) the average composition of the groundwater collected at the Neves Corvo deposit (Portugal) 
is $\mathrm{Na} 67$ and $\mathrm{Cl} 76 \mathrm{mg} \mathrm{l}^{-1}$ (Grimes and de Carvalho, 1994), which plots on the La Zarza deposit mixing line.

\subsection{Chemical speciation and water-rock reactions}

Thermodynamic calculations on the La Zarza and Masa Valverde groundwaters, using the EQ3NR geochemical code (Wolery, 1992), gave results that show certain similarities (Fig. 12) despite the differences in both apparent residence time and redox conditions. The groundwater is close to equilibrium with respect to chalcedony, which indicates water-rock reactions and, in particular, the dissolution of silicate minerals from host rocks by the dilute end-member. Groundwater at both sites is also close to equilibrium, or slightly undersaturated, with respect to carbonate minerals (calcite, rhodocrosite and siderite). At Masa Valverde, it is possible to distinguish a difference between $\mathrm{SO}_{4}$-free samples and $\mathrm{SO}_{4}$-bearing samples, namely between water containing a significant proportion of the dilute end-member and water apparently less affected by such dilution. In the former case, the water is close to equilibrium with calcite, whereas in the latter case it may be undersaturated with respect to the same phase, indicating that reequilibration after acidification through sulphide-mineral oxidation may not be complete. These calculations, made at both sites, demonstrate the occurrence of water-rock reactions and thus at least a partial equilibrium of the groundwater with respect to a mineral assemblage.

As regards metal behaviour, the saturation state with respect to sulphide minerals is worth examining. At the La Zarza deposit, only the groundwater in borehole ZA2 contains detectable sulphide concentrations. Application of the EQ3NR geochemical code to this borehole indicates extensive oversaturation with respect to both pyrite (saturation index $($ S.I. $)=9$ ) and chalcopyrite (Fig. 13), and moderate oversaturation with respect to galena (Fig. 13). These oversaturations may have several single or combined explanations. For example, because during modelling of chemical speciation, EQ3NR considers the total concentration as being only the mobile fraction of elements, macromolecules and colloids/small particles (for which the necessary thermodynamic data are not available) will contribute to an apparent oversaturation; this is in accordance with the VIP results for $\mathrm{Cu}$. Other explanations could be the oxidation of sulphide minerals, and a $\mathrm{pH}$ increase subsequent to reaction with carbonate minerals after oxidation of sulphide minerals. The water is shown to be slightly undersaturated with respect to sphalerite (Fig. 13), whereas in reality the undersaturation may be higher than calculated when one considers that the comparison between the VIP and ICP-MS results that indicate the presence of $\mathrm{Zn}$ as macromolecules or colloids, which are not taken into account by the EQ3NR code. This undersaturation can be explained by the dilution deduced from the $\mathrm{Na}-\mathrm{Cl}$ graphs.

As noted above, despite the very low solubility of sulphide minerals and the absence of detectable sulphide-mineral oxidation in some samples, metal concentrations in the Masa Valverde groundwater show a same order-of-magnitude range as in the La Zarza groundwater and in groundwater away from both deposits. The groundwater saturation state with respect to sulphide minerals cannot be measured directly due to its lack of detectable $\mathrm{H}_{2} \mathrm{~S}$; however, a first approximation of $\mathrm{H}_{2} \mathrm{~S}$ concentration can be made by assuming the groundwater to be in equilibrium with pyrite and examining this equilibrium with respect to other minerals. Results of calculations carried out using EQ3NR indicate $\mathrm{H}_{2} \mathrm{~S}$ concentrations between 0.3 and $7.0 \mu \mathrm{g} 1^{-1}$. These concentrations are in good agreement with the fact that $\mathrm{H}_{2} \mathrm{~S}$ could not be determined by titration with $\mathrm{HgCl}_{2}$ (i.e., a detection threshold no better than $30 \mu \mathrm{g}^{-1}$ ). Therefore, the Masa Valverde groundwater must be either close to equilibrium or undersaturated with respect to pyrite, and equilibrium seems to be a reasonable hypothesis, at least for $\mathrm{SO}_{4}$-free waters. Assuming equilibrium, therefore, the estimated $\mathrm{H}_{2} \mathrm{~S}$ concentration was used to calculate the equilibrium state with respect to other sulphide minerals. The results indicate equilibrium with respect to sphalerite, but oversaturation by several orders of magnitude with respect to chalcopyrite and, to a lesser degree, galena (Fig. 13).

Dissolved $\mathrm{Pb}$ and $\mathrm{Cu}$ concentrations, based on the assumption of equilibrium with respect to galena and chalcopyrite, were calculated and compared with the measured concentrations (Fig. 14). In $\mathrm{SO}_{4}$-free waters these measured concentrations were about $2-3$ orders of magnitude above expected values for $\mathrm{Pb}$, and up to $9-10$ orders of magnitude above expected values for 

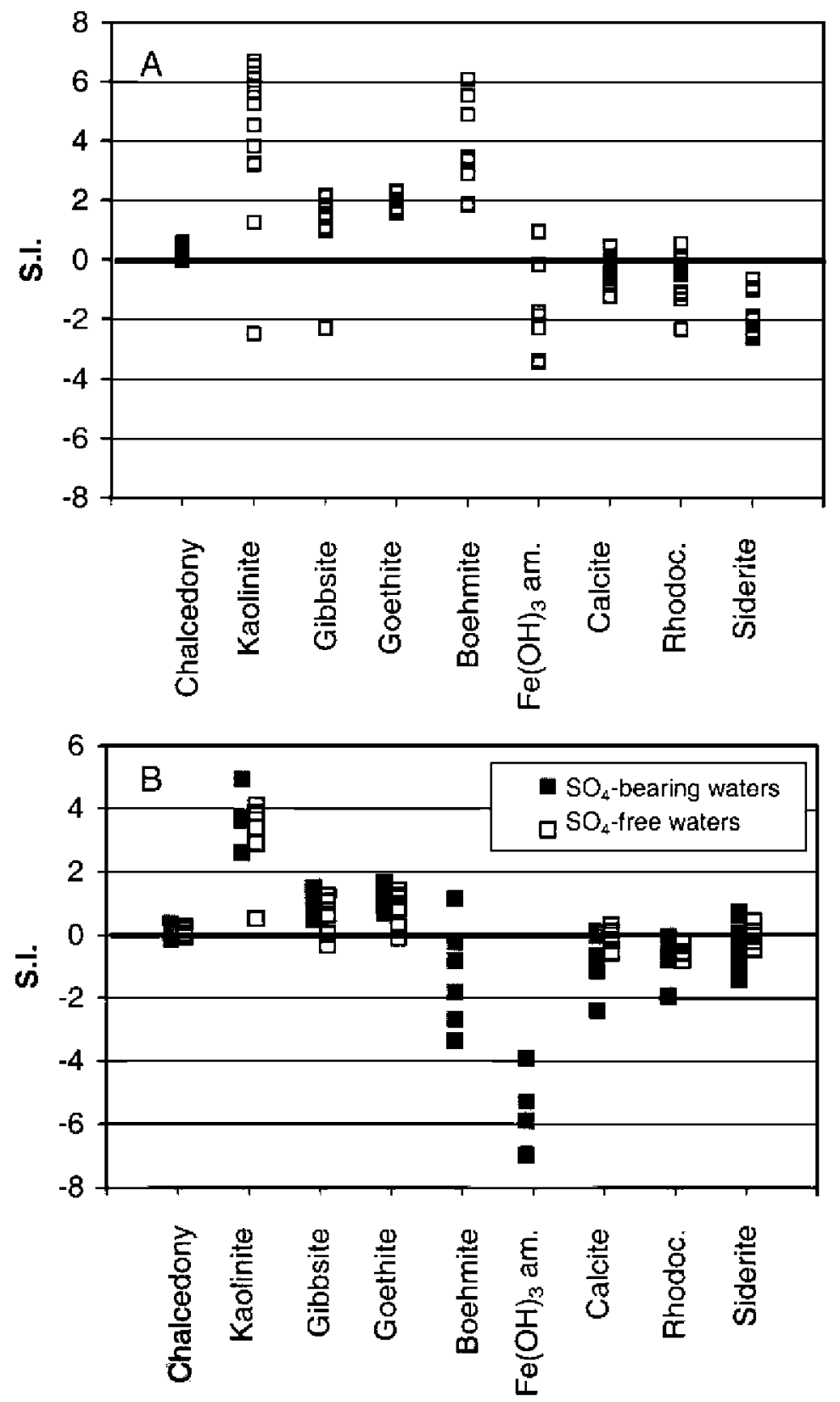

Fig. 12. Saturation index plot calculated using the EQ3NR code (Wolery, 1992) with respect to silicates, oxides, hydroxides and carbonate (calcite, rhodocrosite, siderite) minerals for groundwater at (A) the La Zarza deposit, and (B) the Masa Valverde deposit.

$\mathrm{Cu}$. In $\mathrm{SO}_{4}$-bearing waters, the difference between the expected and measured $\mathrm{Cu}$ concentrations was drastically reduced during modelling because EQ3NR automatically converted part of the $\mathrm{SO}_{4}$ into thiosulphates $\left(\mathrm{S}_{2} \mathrm{O}_{3}\right)$ in accordance with the redox potential.
Although thiosulphates could (a) be present, because they are a metastable species with increasing stability in the presence of pyrite above $\mathrm{pH}=7$ ( $\mathrm{Xu}$ and Schoonen, 1995), and (b) have been oxidized into sulphates after sampling and before $\mathrm{SO}_{4}$ determina- 


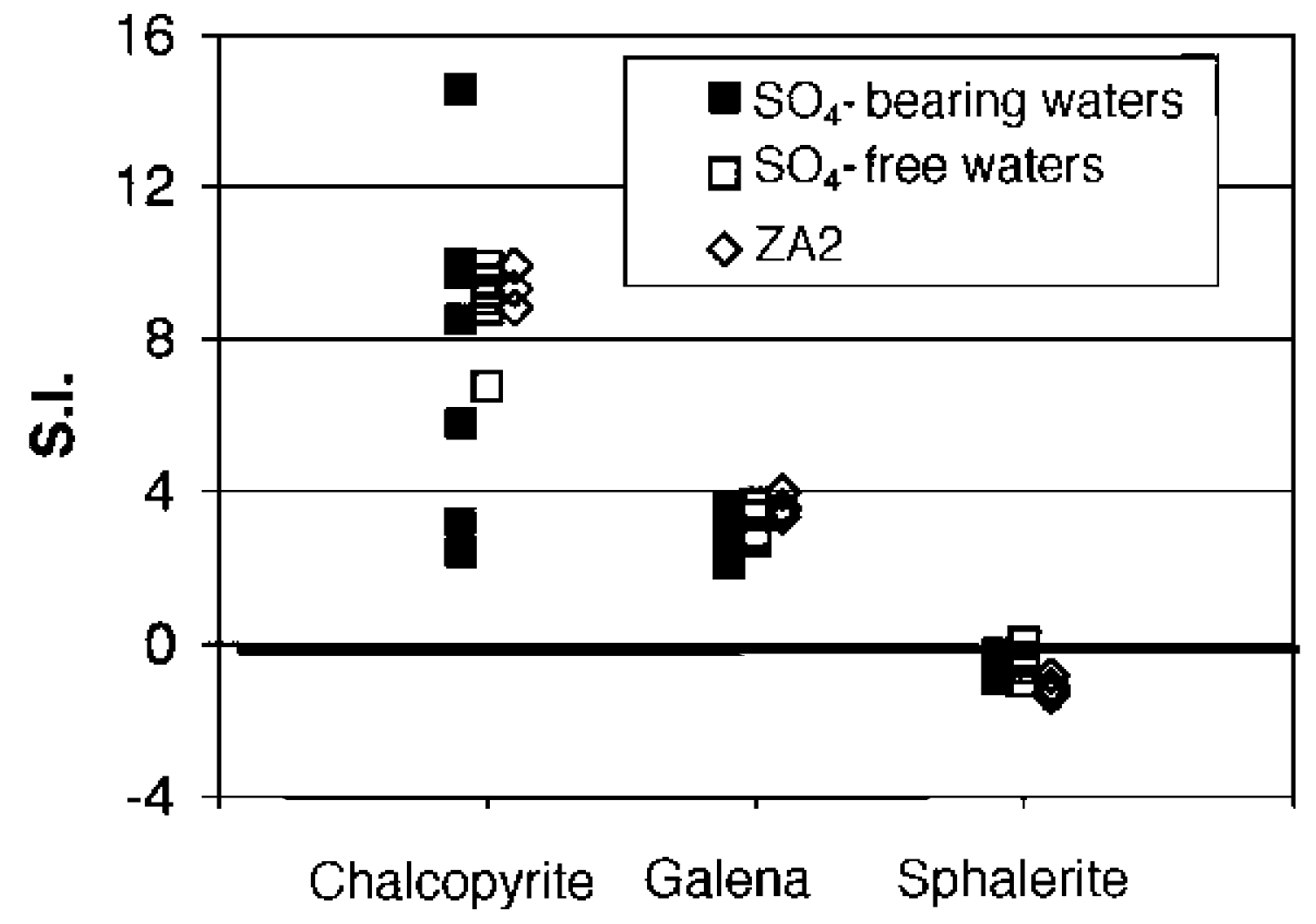

Fig. 13. Saturation index plot calculated using the EQ3NR code (Wolery, 1992) with base-metal sulphide minerals, for groundwater at the Masa Valverde deposit and borehole ZA2, assuming equilibrium with respect to pyrite.

tion, this factor was not investigated by the project. Fig. 14 illustrates how their presence could effectively enhance $\mathrm{Cu}$ solubility, but it does not prove their presence. Moreover, colloidal and dissolved organic matter derived from host-rock/water interaction is also a very efficient sink for metals such as $\mathrm{Cu}, \mathrm{Pb}$ and $\mathrm{Zn}$ (Bruland, 1988; Apte et al., 1995; Benedetti et al., 1996; Sauvé et al., 1998) as well as other forms of colloids.

Clearly, metal speciation differs from one site to the other. On the one hand, for the La Zarza groundwater, comparison of the VIP and ICP-MS results, along with the thermodynamic calculations for borehole $\mathrm{ZA} 2$, indicates that $\mathrm{Cu}, \mathrm{Zn}$ and $\mathrm{Cd}$ are present in significant amounts as macromolecules or adsorbed on colloids/small particles, and that $\mathrm{Pb}$ is dissolved. On the other hand, for the Masa Valverde groundwater, assuming the hypothesis of equilibrium at least for $\mathrm{SO}_{4}$-free waters, it is $\mathrm{Cu}$ and $\mathrm{Pb}$ that occur as macromolecules or colloids whereas $\mathrm{Zn}$ is assumed to be dissolved. The very nature of the colloids/small particles may explain this difference, because the colloid/small-particle form able to adsorb metals can be assumed by a variety of species. At both deposits, $\mathrm{Si}$ and $\mathrm{Mn}$ colloidal species in groundwater are probably not important because of equilibrium with respect to chalcedony and rhodocrosite. However, the presence of Mn colloidal species in the Masa Valverde groundwater cannot be totally excluded in view of the VIP results. Colloidal Al-bearing species may occur in groundwater at both sites, as suggested by the oversaturation with respect to kaolinite, gibbsite and boehmite, which is more marked at La Zarza than at Masa Valverde. The occurrence of Fe-bearing species subsequent to sulphide oxidation at La Zarza, which is supported by over-saturation with respect to goethite.

\subsection{Implications for mineral exploration}

Significant metal concentrations are observed in the Masa Valverde groundwater, even where this is $\mathrm{SO}_{4}^{-}$

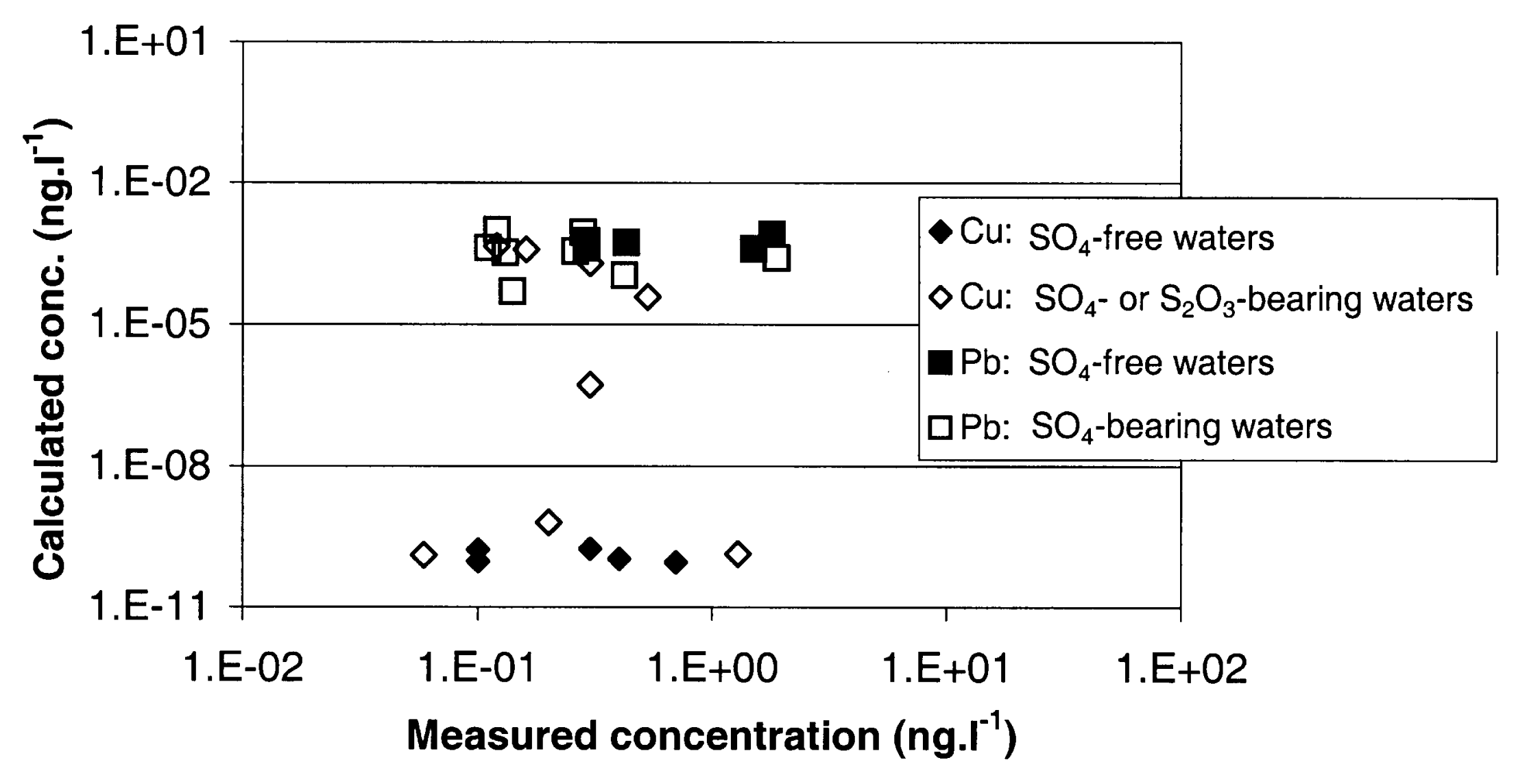

Fig. 14. $\mathrm{Cu}$ and $\mathrm{Pb}$ concentrations expected from equilibrium of the groundwater at the Masa Valverde deposit with respect to pyrite, chalcopyrite and galena, versus total metal concentrations measured by ICP-MS. 
free water (i.e., where no significant oxidation is detected). If it is assumed that these concentrations result from the presence of the sulphide deposit at depths of more than $400 \mathrm{~m}$, then they present two major implications for mineral exploration. Firstly, they widen the field of potential hydrogeochemical methods for 'deep orebody' exploration, at least on the local scale. Secondly, they better constrain the possible mechanisms for the formation of surface anomalies on which other geochemical methods of 'deep orebody' exploration are based. These geochemical methods include enzyme leach and MMI (mobile metal ion) selective digestion, with which successful recent case studies have been recorded (e.g., Clark et al., 1997; Bajc, 1998), as well as the promising use of new devices to trap metals transferred to the surface from buried ore deposits (Malmqvist and Kristiansson, 1982; Wang et al., 1997; Pauwels et al., 1999). Although the dispersion models giving the observed patterns of geochemical response at the surface are not well understood, it is considered that groundwater composition, and particularly groundwater-rock interactions creating chemical-composition anomalies, are partly responsible for the formation of the surface geochemical anomalies.

\subsection{Implications for the application of exploration hydrochemistry in areas with previous mining con- tamination}

The determination of proximity criteria is essential for the successful use of groundwater chemistry as an exploration tool. However, as mentioned earlier, the range of total metal concentrations in groundwater is similar at La Zarza and Masa Valverde, as well as away from the deposits. It is thus impossible, either from the total metal concentration or from the concentration of any particular metal, to discriminate between $\mathrm{SO}_{4}$-bearing groundwater types (e.g., groundwater in contact with an undisturbed ore deposit, groundwater in contact with a partly exploited deposit, or groundwater baseline concentration that results from previous mining activity upstream), sulphate concentrations of all of them mainly attesting to sulphide mineral oxidation.

We have also seen that groundwater metal contents are in part controlled by the formation of complexes and/or by adsorption onto colloids/small particles. The surface complexation model (e.g., Stumm, 1982; Dzombak and Morel, 1987) allows adsorption to be taken into account as a classic complexation reaction, and so adsorption as well as complexation is a reaction with a protonable ligand, implying a dependence on the $\mathrm{pH}$, which must be therefore considered as one of the variables. Data presented in several (metal/ $\left(\mathrm{H}^{+}\right)^{2}$, metal/ $\left.\left(\mathrm{H}^{+}\right)^{2}\right)$ diagrams (Fig. 15) show that it is possible to distinguish $\mathrm{SO}_{4}$-bearing groundwater samples collected in the vicinities of the two deposits from $\mathrm{SO}_{4}$-bearing groundwater samples collected away from the two deposits. The more significant plots are $\left(\mathrm{Cu} /\left(\mathrm{H}^{+}\right)^{2}, \mathrm{~Pb} /\left(\mathrm{H}^{+}\right)^{2}\right),\left(\mathrm{Cu} /\left(\mathrm{H}^{+}\right)^{2}, \mathrm{Cd} /\left(\mathrm{H}^{+}\right)^{2}\right)$, and $\left(\mathrm{Ni} /\left(\mathrm{H}^{+}\right)^{2}, \mathrm{Mn} /\left(\mathrm{H}^{+}\right)^{2}\right)$ in Fig. 15, which show that, at a given $\mathrm{pH}$, groundwater proximity to the ore deposits is clearly indicated by higher $\mathrm{Cd}$ and $\mathrm{Pb}$ concentrations relative to $\mathrm{Cu}$, and higher $\mathrm{Mn}$ relative to $\mathrm{Ni}$. This means that in areas where the baseline quality of groundwater reflects past mining activities, the chemical composition of the groundwater can provide relevant information for ore deposit exploration, provided a sufficiently complete database is available.

\subsection{Implication for studies of environmental pre- mining conditions}

Total metal concentration, rate of transport, overall mobility in water, and metal bioavailability all depend on metal speciation (e.g., Buffle and de Vitre, 1994; Tessier and Turner, 1995), which is thus a factor requiring increasing attention. Nevertheless, the present results, particularly those of the $\mathrm{SO}_{4}$-free groundwater at Masa Valverde, illustrate that total metal concentration is drastically more important than mobile metal species. Even though the studied metal concentrations do not exceed drinking-water standards, they are far from negligible, even where there has been no significant oxidation. A natural baseline-quality study before the commencement of mining operations appears, therefore, to be of prime importance in order to determine realistic achievable targets for remediation.

This then poses the problem of suitable methods for estimating natural total-metal background concentrations in water at abandoned mine sites. A priori, the natural metal concentrations can be estimated through examination of historical records, comparison with non-mined areas and/or using predictive 

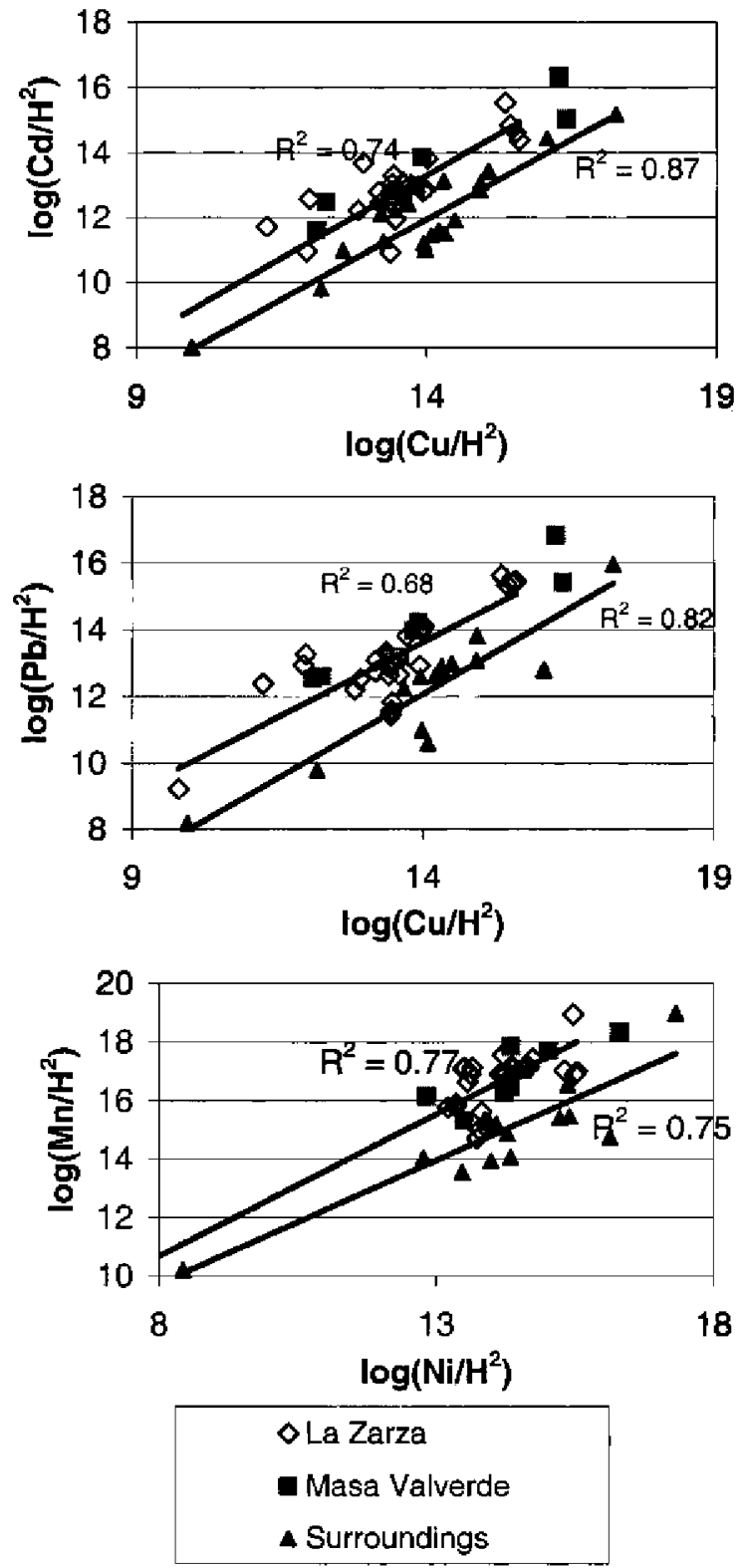

Fig. 15. $\left(\log \left(\operatorname{metal} / \mathrm{H}^{2}\right), \log \left(\operatorname{metal} / \mathrm{H}^{2}\right)\right)$ plots illustrating differences in the metal behaviour of groundwater in the immediate vicinity of the deposits with respect to the baseline quality of the area.

geochemical modelling (Runnells et al., 1992). Predictive geochemical modelling for surface water in the case of acid drainage probably indicates an upper limit for total metal contents, at least where the reaction kinetics are not taken into account (Runnells et al., 1992). Conversely, assuming equilibrium con- ditions, the groundwater results described above illustrate how predictive geochemical modelling will indicate a lower limit for total metal concentrations because the formation of colloids and adsorption on small particles is not taken into account by the geochemical codes. 


\section{Conclusions}

The differing major-element chemistry of the groundwater at the La Zarza and Masa Valverde massive sulphide deposits is due mainly to the different hydrogeological situations and to previous mining activity at one site. The La Zarza deposit is located in an area of hydrological recharge, has been partly exploited, and its groundwater has a lower $\mathrm{pH}$ and higher Eh and $\mathrm{SO}_{4}$ than the groundwater at the Masa Valverde deposit which, deeply buried, is located in an area of water discharge and is unworked. The respective pathway of each groundwater type is indicated by its $\mathrm{Na} / \mathrm{Cl}$ ratio, with an increase in Na concentration during deep circulation.

Despite these differences, the metals and traceelement chemistry of the groundwater at the two deposits is, with a few exceptions, similar. Moreover, it does not differ drastically from the baseline quality of groundwater in this area of intense past mining activity. Total metal concentrations in the groundwater at both deposits are enhanced by the formation of complexes and/or by metal adsorption on colloids or small particles. This has been demonstrated by comparing ICP-MS data with data obtained using (i) a special analytical technique-the Voltammetric In situ Profiling (VIP) System, and (ii) calculation with the EQ3NR geochemical code. At the deep and undisturbed Masa Valverde deposit where redox conditions are very low, the total metal concentrations in the groundwater are several orders of magnitude (up to $10^{8}-10^{9}$ for $\mathrm{Cu}$ ) higher than would be expected from the very low solubility of sulphide minerals. The results have implications as regards both mineral exploration and the environment.

Where mineral exploration is concerned, the total metal concentrations appear to be significantly enhanced in groundwater, even when the sulphides are unoxidized. This fact increases the potential of groundwater chemical composition as an ore-deposit exploration technique.

Where the environment is concerned, knowledge of the natural concentrations of metals in the groundwater prior to mining operations is of particular importance for preparing realistic and technically achievable remediation plans. For new ventures, the relevant data can be acquired through baseline quality monitoring before exploitation. For sites already con- taminated by exploitation, it should be borne in mind that predictive geochemical modelling can underestimate the metal concentrations because the geochemical codes lack data concerning metal adsorption on colloids or small particles.

\section{Acknowledgements}

This research was partly supported by the European Community under the Brite-EuRam programme (DG XII, contract No. BRPR-CT97-0374), by BRGM, Inima, Idronaut, and by MEC/SPAIN (projects GR2-0135, UE 95-007 and UE 98-0027). It benefited greatly from the endorsement of J.Y. Calvez (E.U.). The authors also wish to acknowledge M. Brach, J.-C. Foucher, A. Molina, F. Jerez, J. Samper, R. Cueto, E. García and A. Sina for their technical assistance, and P. Skipwith for editing the English text. The manuscript benefited from the constructive comments of K. Hudson-Edwards and Javier GarciaGuinea.

\section{References}

Apte, S.C., Benko, W.I., Day, G.M., 1995. Partitioning and complexation of copper in the Fly River, Papua New Guinea. J. Geochem. Explor. 52, 67-79.

Archer, A.R., Main, L.A., 1971. Casino, Yukon-a geochemical discovery of unglatiated Arizona-type porphyryBoyle, R.W., McGerrigle, J.I. (Eds.), Proceeding of 3rd International Geochemistry Exploration Symposium special, vol. 11. Canadian Institute of Mining and Metallurgy, Toronto, Ontario, pp. 6777.

Bajc, A.F., 1998. A comparative analysis of enzyme leach and mobile metal ion selective extractions; case studies from glaciated terrain, northern Ontario. J. Geochem. Explor. 61 (1-3), $113-148$.

Belmont-Hébert, C., Tercier-Waeber, M.L., Buffle, J., Fiaccabrino, G.C., de Rooij, N.F., Koudelka-Hep, M., 1998. Gel-Integrated Microelectrode Arrays for direct voltammetric measurements of heavy metals in natural waters and other complex media. Anal. Chem. 70, 2949-2956.

Benedetti, M.F., van Riemsdijk, W.H., Koopal, L.K., Kinniburgh, D.G., 1996. Metal ion binding by natural organic matter: from the model to the field. Geochim. Cosmochim. Acta 60, 25032513.

Buffle, J., De Vitre, R.R., 1994. Chemical and Biological Regulation of Aquatic Systems. Lewis, London.

Bruland, K.W., 1988. Trace element speciation: organometallic compounds and metalorganic ligand complexes. Appl. Geochem. 3, 75 . 
Cameron, E.M., 1977. Geochemical dispersion in lake waters and sediments from massive sulphides mineralization, Agricola Lake area, Northwest Territories. J. Geochem. Explor. 7, 327-348.

Cameron, E.M., 1978. Hydrogeochemical methods for base metal exploration in the northern Canadian Shield. J. Geochem. Explor. 10, 219-243.

Cameron, E.M., Prévost, C.L., McCurdy, M., Hall, G.E.M., Doidge, B., 1998. Recent (1930s) natural acidification and fish-kill in a lake that was an important food source for an Inuit community in northern Québec, Canada. J. Geochem. Explor. 64, 197-213.

Clark, J.R., Yearger, J.R., Hoffman, E.L., 1997. Innovative enzyme leach provides cost-effective overburden/bedrock penetration. Abstracts, Exploration '97, Toronto, Ontario, 7 pp.

Costa, L.R., Parilla, F., 1992. Structure économique et minière de la bande pyritique Ibérique. In: Mañana, R. (Ed.), World Mining Congress, Madrid, 25-29 May 1992, vol. 2, pp. 617-625.

Dzombak, D.A., Morel, F.M.M., 1987. Adsorption of inorganic pollutants in aquatic systems. J. Hydraul. Eng. 113, 430-475.

Duttweiller Kelley, K., Taylor, C.D., 1997. Environmental geochemistry of shale-hosted $\mathrm{Ag}-\mathrm{Pb}-\mathrm{Zn}$ massive sulfide deposits in northwest Alaska: natural background concentrations of metals in water from mineralized areas. Appl. Geochem. 12 (4), $397-409$.

Elbaz-Poulichet, F., Dupuy, C., 1999. Behaviour of rare-earth elements at the frshwater-seawater interface of two acid mine rivers: the Tinto and Odiel (Adalucia, Spain). Appl. Geochem. $14,1063-1072$.

Elbaz-Poulichet, F., Leblanc, M., 1969. Transfert de méteaux à une province minière à l'océan par les fleuves acides (Rio Tinto, Espagne). C. R. Acad. Sci. Fr., Ser. IIa 322, 1047-1052.

de Geoffrey, J., Wu, S.M., Heins, R.W., 1967. Geochemical coverage by spring sampling method in the southwest Wisconsin zinc area. Econ. Geol. 62, 679-697.

Gran, G., 1952. Determination of the equivalence point in potentiometric titrations. Part II. Analyst 77, 661-671.

Grimes, D.J., de Carvalho, D., 1994. Geochemical exploration studies in the Portuguese pyrite belt. In: Berger, B.R. (Ed.), Advances in Research on Mineral Resources, USGS 2081, Washington, $53-77$.

Hamet, J., Delcey, R., 1971. Age, synchronisme et affiliation des roches rhyolitiques de la province pyrito-cuprifère du Baixo Alentejo (Portugal): mesures isotopiques par la méthode ${ }^{87} \mathrm{Rb} /$ ${ }^{87}$ Sr. C. R. Acad. Sci. Fr. 272-D, 2143-2146.

Leistel, J.M., Marcoux, E., Thiéblemont, D., Quesada, C., Sánchez, A., Almodóvar, G.R., Pascual, E., Sáez, R., 1998. The volcanichosted massive sulphide deposits of the Iberian Pyrite Belt. Review and preface to the thematic issue. Miner. Deposita 33, 2 30.

Leybourne, M.I., Goodfellow, W.D., Boyle, D.R., 1998. Hydrogeochemical, isotopic, and rare earth element evidence for contrasting water-rock interactions at two undisturbed $\mathrm{Zn}-\mathrm{Pb}$ massive sulphide deposits, Bathurst Mining Camp, N.B., Canada. J. Geochem. Explor. 64, 237-261.

Lydon, J.W., 1992. Volcanogenic massive sulphide deposits: Part 1. A descriptive model. Geosci. Can. Rep., Ser. 3, 145-153.

Malmqvist., E.L., Kristiansson, K., 1982. A method for indicating and identifying concealed deposits. European Patent No 89998.

Nelson, C.H., Lamothe, P.J., 1993. Heavy metal anomalies in the Tinto and Odiel rivers and estuary system, Spain. Estuaries 16, $495-511$.

Oliveira, J.T., 1990. South Portuguese Zone: 1) Introduction, 2) Stratigraphy and synsedimentary tectonism. In: Dallmeyer, R.D., Martinez Garcia, E. (Eds.), Pre-Mesozoic Geology of Iberia. Springer-Verlag, Berlin, pp. 333-347.

Pauwels, H., Baubron, J.C., Freyssinet, Ph., Chesneau, M., 1999. Sorption of metallic compounds on activated carbon: application to the exploration for concealed deposits in Southern Spain. J. Geochem. Explor. 66, 115-133.

Quesada, C., 1991. Geological constraints on the Paleozoic tectonic evolution of tectonostratigraphic terranes in the Iberian Massif. Tectonophysics $185,225-245$.

Routhier, P., Aye, F., Boyer, C., Lécolle, M., Molière, P., Picot, P., Roger, C., 1980. La ceinture sud-lbérique à amas sulfurés dans sa partie Espagnole médiane. Tableau géologique et métallogénique. Synthèse sur le type amas sulfurés volcano-sédimentaires. 26th Inter. Geol. Congr., ParisMem. BRGM Orléans, vol. 94,265 pp.

Runnells, D.D., Shepherd, T.A., Angino, E.E., 1992. Metals in water-determining natural background concentrations in mineralized areas. Environ. Sci. Technol. 26 (12), 2316-2323.

Sauvé, S., McBridge, M., Hendershot, W., 1998. Soil solution speciation of lead (II): effects of organic matter and $\mathrm{pH}$. Soil Sci. Soc. Am. J. 62, 618-621.

Schermerhorn, L.J.G., 1971. An outline stratigraphy of the Tberian pyrite belt. Bol. Geol. Min. Esp. 82, 238-268.

Shartsev, S.L., Udodov, P.A., Rasskazov, N.M., 1975. Some features of the migration of microcomponents in neutral waters of the supergene zone. J. Geochem. Explor. 4, 433-439.

Silva, J.B., Oliveira, J.T., Ribeiro, A., 1990. South Portuguese zone. Structural outline. In: Dallmeyer, R.D., Martinez Garcia, E. (Eds.), Pre-Mesozoic Geology of Iberia. Springer Verlag, Berlin, pp. $348-362$.

Simpson, P.R., Breward, N., Flight, D.M.A., Lister, T.R., Cook, J.M., Smith, B., Hall, G.E.M., 1996. High-resolution regional hydrogeochemical baseline mapping of stream water of Wales, the Welsh borders and West Midlands region. Appl. Geochem. $11,621-632$.

Strauss, G.K., Madel, J., 1974. Geology of massive sulphide deposits in the Spanish-Portuguese Pyrite Belt. Geol. Rundsch. 63 (1), 191-211

Strauss, G.K., Roger, G., Lécolle, M., Lopera, E., 1981. Geochemical and geologic study of the volcanic-sedimentary sulfide orebody of La Zarza, Huelva Province, Spain. Econ. Geol. 76, $1975-2000$.

Stumm, W., 1982. Surface chemical theory as an aid to predict the distribution and the fate of trace constituents and pollutants in the aquatic environment. Water Sci. Technol. 14, 481-489.

Taufen, P., 1997. Ground waters and surface waters in exploration geochemical survey. In: Gubins, A.G. (Ed.), Proceedings of Exploration 97, Toronto, Canada, 271-284.

Tercier, M.-L., Buffle, J., Graziottin, F., 1998a. A novel voltammetric in situ profiling system for continuous real-time monitoring 
of trace elements in natural waters. Electroanalysis 10, 335 363.

Tercier-Waeber, M.-L., Belmont-Hebert, C., Buffle, J., 1998b. Realtime continuous $\mathrm{Mn}$ (II) monitoring in lakes using a novel voltammetric in situ profiling system. Environ. Sci. Technol. 32, 1515-1521.

Tessier, A., Turner, D.R., 1995. Metal Speciation and Bioavailability in Aquatic Systems. Wiley, New York.

Van den Boogaard, M., 1967. Geology of the Pomarao region (southern Portugal). PhD thesis, Rotterdam, 113 pp.

Wang, X., Cheng, Z.L.Y., Xie, X., 1997. Nanoscale metals, earthgas and mobile forms in overburden in wide-spaced regional exploration for giant deposits in overburden terrains. J. Geochem. Explor. 58, 63-72.

Wolery, T.J., 1992. EQ3NR, A Computer Program for Geochemical Aqueous Speciation-Solubility Calculations: Theoretical Manual, User's guide, and related documentation (version 7.0). Lawrence Livermore National Laboratory, Livermore, CA, $246 \mathrm{pp}$.

Xu, Y., Schoonen, M.A.A., 1995. The stability of thiosulfate in the presence of pyrite in low-temperature aqueous solutions. Geochim. Cosmochim. Acta 59, 4605-4622. 